\title{
"O que o rei não viu": música popular e nacionalidade no Rio de Janeiro da Primeira República*
}

\author{
Letícia Vidor de Sousa Reis
}

\section{Resumo}

Neste artigo, por meio do acompanhamento do processo de legitimação do samba carioca durante as três primeiras décadas do século XX, a autora investiga de que maneira esse ritmo deixa, paulatinamente, os redutos negros e vai se firmando como nacional. Tal processo foi conflituoso e ambíguo por estar vinculado ao reconhecimento social do negro no Brasil. Dessa forma, se o ritmo fruído era o mesmo, seus significados e usos eram diversos. Observa-se, então, uma cisão na sensibilidade estética das elites do período no que se refere à essa música popular, o que provocará uma oscilação entre o elogio e o repúdio à mesma. Esta dupla perspectiva relaciona-se a um dos grandes dilemas dos intelectuais e governantes da época quanto à constituição do corpo político da Primeira República. Se, de um lado, os critérios darwinistas sociais eram um empecilho à plena incorporação do negro à esfera pública, de outro lado, as tradições culturais negras, preteridas como sinal de "decadência", eram já parte constituinte da expressão do nacional. Finalmente, investiga como esse dilema se traduziu na infrutífera tentativa de criação de uma simbologia popular por parte da jovem República, em busca de sua legitimidade política.

\footnotetext{
* Esse artigo é uma versão modificada de parte de minha tese de doutorado intitulada "Na batucada da vida: samba e política no Rio de Janeiro (1889-1930)", defendida em 1999 junto ao Programa de Pós-Graduação em Antropologia Social da Faculdade de Filosofia, Letras e Ciências Humanas da Universidade de São Paulo, sob orientação da Prof $\operatorname{Dr}^{a}$ Paula Montero.
} 
Palavras-chave: música popular, Primeira República, 1900-1930, tradições culturais negras, negro, simbologia popular, samba carioca.

\section{Abstract \\ "What the king hasn't seen": popular music and nationality in Rio de Janeiro during the First Republic.}

Accompanying the legitimization process of the carioca samba during the first three decades of the 20th Century, the author investigates how this rhythm gradually has gone from black ghettos to a national sphere. Such process was conflicting and ambiguous for being attached to Brazil's social recognition of black people. Therefore, if the rhythm was the same, its meaning and usage were diverse. The elites' esthetic sensitivity split during the period of time that referred to tath popular music, which has provoked an oscillation between recognition and rejection. This double perspective is related to one of the intellectuals' and governors' great dilemmas concerning the constitution of a political body in the First Republic. If, on one hand, the social Darwinist criteria were obstacles preventing the incorporation of black people in the public sphere, on the other, the black cultural traditions - set aside as a sign of "decadence" - had already become a national exponent. Finally, it is investigated how this dilemma showed no results in attempting to create a popular symbolization during the First Republic towards its political legitimacy.

Keywords: Popular music, First Republic, 1900-1930, black cultural traditions, Negro, popular symbolization, carioca samba.

\section{Résumé}

"Ce que le roi n'a pas vu»: musique populaire et nationalité dans le Rio de Janeiro de la Première République

À travers l'analyse du processus de légitimisation de la samba carioca pendant les trois premières décades du XXème siècle, l'auteur montre comment ce rytme quitte, peu à peu, les redoutes des Noirs pour s'affirmer sur le territoire national brésilien. Un tel processus a été ambigu et plein de conflits étant donné qu'il était lié à la reconaissance sociale du Noir au Brésil. C'est ainsi que, si ce rytme de la juissance était le même, ses significations et ses usages étaient très diversifiés. On remarque alors une scission dans la sensibilité esthétique des élites, à cette époque-là, en ce qui concerne cette musique. Cette double 
perspective se rapporte à l'un des grands dilemmes des intellectuels et des dirigeants, à l'époque, pour la constitution d'un corps politique sous la Première République. Si, d'un côté, les critères sociaux darwiniens étaient une entrave à la pleine intégration du Noir dans la sphère publique, d'un autre côté, les traditions culturelles noires, en tant que signes de «décadence», faisaient déjà partie intégrante de l'expréssion de la nation. Enfin, on y analyse comment ce dilemme se traduit par l'échec de l'essai de création d'une symbologie populaire par la jeune République, à la recherche de sa légitimité politique.

Mots-clés: musique populaire, Première République, 1900-1930, traditions culturelles noires, Noir, symbologie populaire, samba carioca. 
Não existe razão

que um samba não vença

é toda minha ilusão

e também minha crença

(Batatinha - Lula Carvalho)

$\mathbf{R}$ elatando as impressões do escritor carioca João do Rio a respeito do aprofundamento da cisão social provocada pela reforma urbana sofrida pela cidade do Rio em princípios do século XX, Nicolau Sevcenko (1998b:543) comenta: "Na verdade, [como constata João do Rio], surgiam dois Rios de Janeiro frutos da reforma, o da Regeneração, da nova norma urbanística, racional e técnica, e o outro, o labirinto das malocas, do desemprego compulsório e 'livre de todas as leis'”.

Porém, os domínios territoriais e sociais dos "dois Rios de Janeiro" muitas vezes se confundiam. Isso provocava a indignação de alguns, como podemos observar numa crônica de 1906, assinada pelo poeta Olavo Bilac, que lamentava a

‘selvagem’ presença negra na recém-inaugurada Avenida Central, principal ícone da Regeneração: [...] Num dos últimos domingos vi passar pela Avenida Central um carroção atulhado de romeiros da Penha: e naquele amplo boulevard esplêndido, sobre o asfalto polido, contra a fachada rica dos prédios altos, contra as carruagens e carros que desfilavam, o encontro do velho veículo [...] me deu a impressão de um monstruoso anacronismo: era a ressurreição da barbaria — era uma idade selvagem que voltava, como uma alma do outro mundo, vindo perturbar e envergonhar a vida da idade civilizada [...] Ainda se a orgia desbragada se confinasse ao arraial da Penha! Mas não! acabada a festa, a multidão transborda como uma enxurrada vitoriosa para o centro da urbs [...] (Bilac, 1906)

Tentemos compreender a razão de sua ira, colocando-nos na perspectiva do poeta: a cidade havia sido remodelada para possibilitar a circulação de automóveis e bondes elétricos; no entanto, vinha aquela "enxurrada vitoriosa" de "romeiros da Penha", montados em seu "carroção", desaguar justamente ali, na Avenida Cen- 
tral! Fica evidente a idéia de que o centro da cidade, com sua nova arquitetura e equipamentos urbanos, deveria ser desfrutado apenas pelas camadas mais abastadas da população, enquanto o restante deveria confinar-se às áreas periféricas.

Contudo, essa nova lógica de ocupação do espaço urbano não conseguiria se impor facilmente, como por certo pretendiam seus mentores. Afinal de contas, aquele mesmo território estava tradicionalmente marcado por intensa circulação das camadas mais pobres da cidade. As maltas de capoeira, por exemplo, numerosas durante o Segundo Reinado, disputaram palmo a palmo a hegemonia sobre os bairros centrais da capital. ${ }^{1}$ As ruas daquela região também eram tomadas pelos populares durante o Carnaval desde meados do século passado, seja jogando entrudo, desfilando fantasiados de velhos, príncipes e diabinhos, de forma autônoma ou como participantes de cordóes e zé-pereiras, ou simplesmente assistindo aos préstitos das "grandes sociedades" carnavalescas. ${ }^{2}$ Além disso, havia também as festas cívicas e religiosas, que pontuavam o calendário do período imperial. Ao lado das festas oficiais da realeza, organizou-se também uma agenda de festas populares, como as cavalhadas, congadas, batuques, folia de Reis e festa do Divino. Grande parte das festividades tinham como palco a área central da cidade (Schwarcz, 1998:247-278).

Porém, além do privilégio de uso exclusivo do centro da cidade pelas elites, as críticas de Bilac deixam transparecer também uma explícita condenação à cultura popular, aliás um outro item caro à política da Regeneração. Dessa forma, a festa dos romeiros seria uma "orgia desbragada" que, por isso mesmo, deveria se restringir ao "arraial da Penha".

Que "alma do outro mundo" era esta que tanto o apavorava? Que ameaça traria quando, insistindo em sair do domínio a ela destinado, adentrava o coração da urbs? A julgar pelo texto, o perigo era que viesse a reinstaurar a barbárie no lugar da civilização. E, como a referência diz respeito à Festa da Penha, um local privilegiado de encontro social e principalmente musical de negros e mestiços, o alvo é certeiro: a condenação recai aqui sobre as tradições culturais negras.

$\mathrm{Na}$ verdade, o esforço conjunto das elites e do governo oligárquico da Primeira República ia no sentido de contenção das assim denominadas "classes perigosas", 3 especialmente no tocante à sua herança africana. Contudo, apesar das vertigens que causava a Bilac e das tentativas de reprimi-la, a presença negra foi, pouco a pouco, se fazendo sentir na cidade. $\mathrm{E}$ isso sob as formas culturais 
sensíveis da música, da festa, do canto, da dança: havia a popular Festa da Penha, a festa do Carnaval, as rodas de samba na casa das "tias" baianas (em especial a da "tia" Ciata), as sedes das sociedades carnavalescas (ranchos e cordões), os salóes de bailes populares e o teatro de revistas, dentre outros divertimentos.

As primeiras décadas deste século marcaram a entrada definitiva do Brasil na chamada modernidade com a introdução do rádio, da gravação de discos, do gramofone e do telefone, entre outros. Contudo, tais benefícios estavam desigualmente distribuídos pelo conjunto da sociedade, ainda que fossem uma aspiração de todos. Como afirma Sevcenko (1998b), as classes populares vislumbravam na modernidade algumas brechas que lhes oferecessem alguma oportunidade de ascensão social.

Nesse sentido, a música oferecia-se como uma possibilidade de inserção das classes populares na era moderna por meio da ainda incipiente cultura de massas. Porém, para fazê-lo, não lhes era possível que se opusessem frontalmente às censuras, aos constrangimentos e às restriçóes que lhes eram impostos. Afinal de contas, como sabiamente alertava o título de uma peça de teatro rebolado, encenada em 1928, Manda quem pode (J. Cristobal e Sá Pereira).

Nesse artigo, procuro entrever como, por meio da música, as classes populares conquistam a ampliação de espaço social e político durante a Primeira República, observando com quem seus agentes se aliam e com quem se indispóem nessa empreitada. Enfrentando-se indiretamente com as censuras e proibições, suas atitudes combinarão, simultaneamente, acato com desacato, isto é, uma aparente adesão à ordem que esconde sempre um desrespeito à mesma. A galhofa e a pilhéria serão recursos largamente utilizados por eles, tanto em seus confrontos com as autoridades como nas querelas que tinham entre si.

Não foi minha intenção aqui reconstituir a história da música popular carioca nas três primeiras décadas do século XX. O que procurei fazer foi interpretar a maneira pela qual uma certa modalidade de samba, produzida no Rio de Janeiro nas primeiras três décadas do século XX, deixa, paulatinamente, os redutos populares e, ao longo das décadas de 1930 e 1940, vai se firmando, num tempo surpreendentemente breve, como um dos mais destacados ícones nacionais, tanto para dentro como para fora do país. Os outros gêneros musicais produzidos no Brasil passarão então a ser vistos como regionais ${ }^{4}$ (Vianna, 1995:111). 


\section{As tradições culturais negras: entre a repressão e a exaltação}

No período que medeia entre o final do século XIX e as primeiras três décadas do século XX, observa-se um enfoque ambivalente por parte de literatos, intelectuais e políticos brasileiros em relação à cultura negra. Deparamos com uma condenação de práticas consideradas "bárbaras" e, simultaneamente, com um enaltecimento das mesmas, exaltadas como produtos da "originalidade nacional".

Por um lado, a cultura negra é apreendida pelo critério da falta: as danças e os ritmos negros não têm "estética nem arte" (Freitas, 1985 [1921]:153), não possuem "tom nem som" e tampouco gozam de "espírito e gosto" (apudRodrigues, 1977 [1933]:157). Os instrumentos musicais dos negros são "rudes", "bárbaros" e fazem uma "algazarra infernal".

Contudo, de outro lado, esboça-se uma visão que tende a conceber essa mesma cultura como dotada de conteúdo, sendo que algumas tradições culturais negras serão, pouco a pouco, representadas como nacionais. Como já notei em estudo anterior sobre a capoeira (Reis, 2000), ao mesmo tempo em que é criminalizada pelo Código Penal de 1890, surge uma representação positiva dessa luta que deplora os que vêem nela apenas o que tem de "mau e bárbaro" e a reclama como "nossa gymnastica nacional, herança da mestiçagem no conflito de raças" (Moraes Filho, 1979 [1893]:257).

Observe-se que o autor dessa assertiva, o folclorista baiano Mello Moraes Filho, busca aqui uma associação entre mestiçagem e nacionalidade, uma vez que a brasilidade da capoeira é atribuída justamente à sua origem híbrida. No entanto, a capoeira que vai se tornando um esporte em âmbito nacional, embora seja uma luta mestiça não é aquela das elites cariocas da virada do século XIX para o século XX, as quais tinham para ela um projeto nacional, mas a capoeira popular baiana, alicerçada em um projeto étnico que ganha importância a partir da década de 1930 em Salvador (Reis, 2000). Porém, é possível notar uma certa proximidade entre algumas idéias e práticas daquela capoeira ilustrada carioca e a capoeira popular baiana. Em ambas, por exemplo, ressalta-se uma forte preocupação em difundir sua prática como um esporte, embora este seja representado de forma diversa.

Não existe, assim, uma ruptura entre esses dois modos de "esportização" da capoeira, observando-se aqui um movimento dinâmico de renovação de sentidos sociais que põe em contato as 
culturas branca e negra no país. Se, de um lado, a cultura negra se embranquece, de outro a cultura branca se enegrece, o que se desenrola, evidentemente, sob o signo da dominação e tem, como sua necessária contrapartida, a confrontação negra. Para evitarmos a armadilha de uma redução dicotômica da cultura em dois pólos, o "popular" e o "erudito", talvez possamos chamar a esse modelo híbrido da capoeira popular baiana, que se tornou nacional, de uma sorte de "formação cultural de compromisso" (Ginzburg, 1991).

Também em relação ao maxixe podemos observar uma dupla percepção que aponta, simultaneamente, para a admiração e para a censura. O maxixe - uma dança e um gênero musical - teria surgido nos bailes da chamada "pequena África do Rio de Janeiro", por volta da década de 1870 , tendo se vulgarizado em princípios do século XX. Condenado por ser "lúbrico" e "enquadrar-se admiravelmente dentro da canalhice bárbara" (Efegê, 1974:162) seria, no entanto, levado a Paris, no começo do século XX, por Duque, membro de uma família baiana abastada que se celebrizaria juntamente com suas partenaires nos requebros de la matchiche, a chamada "dança nacional" do Brasil.

Esta dupla perspectiva, que marca particularmente a sensibilidade estética das elites em relação à cultura popular, relaciona-se a um dos grandes dilemas de grande parte dos intelectuais e governantes no que se refere à constituição do corpo político da Primeira República. Naquele momento, os critérios darwinistas sociais eram um empecilho à plena incorporação do negro à esfera pública. Porém, em contrapartida, as tradições culturais negras, preteridas como sinal de "decadência", eram já parte constituinte da expressão do nacional.

Como explica Maria Lúcia Montes (1998) em sua análise sobre as matrizes barrocas da cultura brasileira, a tradição cultural ibérica barroca no continente americano "era capaz de soldar num mesmo todo o alto e o baixo, as elites e a grossa massa do povo, tendo por mediação fundamental esta forma por excelência sensível, sensual, essencialmente estética, de transmissão de um ethos e de uma visão de mundo representada pela festa" (p.157). No entanto, a partir de princípios do século XIX, com a formação dos Estados nacionais latino-americanos, essa cultura da festa de heranças barrocas, que não separa o sagrado do profano, será aos poucos preterida pelas elites e perderá a hegemonia, permanecendo restrita ao universo das classes populares. 
Se no barroco as expressões populares negras se combinavam com a política porque a esfera pública não se separava da privada, a República brasileira, ao laicizar o Estado, irá abandonar aquela gramática política anterior e terá que se enfrentar com a dificuldade de criar as regras de um novo pacto social.

Esse divórcio entre cultura e política atenua-se apenas quando as teorias darwinistas sociais entram em declínio e começa a afirmar-se uma interpretação mais social do país, tendência esta que se tornaria dominante a partir da década de 30, com a publicação dos trabalhos de Gilberto Freyre (1933) e Sérgio Buarque de Holanda (1936), dentre outros.

\section{Na pista do "mistério do samba"}

O samba carioca, do modo como o conhecemos atualmente, consagrado de norte a sul do país (e mesmo no exterior) como o ritmo nacional por excelência, na verdade parece ter se constituído enquanto tal muito recentemente. Entretanto, ainda que pensemos no samba como um símbolo nacional reconhecido no nível interno, é duvidoso que tenha conquistado plena aceitação. Além do mais, esse processo de legitimação, ainda em curso, é ambíguo, como o é o lugar do negro (ou das manifestações culturais negras) na sociedade brasileira, oscilando ainda entre a exaltação e a detração.

A metamorfose do samba de música negra em música nacional ainda é pouco estudada. Hermano Vianna empreendeu uma primeira análise mais aprofundada sobre esse tema em seu livro $O$ Mistério do Samba (1995). Por meio do estudo do processo de nacionalização do samba no Brasil, cuja ênfase recai sobre o período compreendido entre as décadas de 1910 e 1930, Vianna enfoca a especificidade do padrão de relações raciais no país e a vinculação entre a música popular e a construção da identidade nacional.

Para o autor, a nacionalização do samba é a coroação de um processo secular de interação das chamadas cultura popular e erudita, proporcionada pela atuação de "mediadores culturais", responsáveis pelo intercâmbio de elementos entre essas duas esferas de cultura. Neste sentido, Vianna considera emblemático um encontro entre membros da elite intelectual da época e músicos populares para uma "noitada de violão", ocorrido no Rio de Janeiro em 1926 (1995:19-36). 
Contudo, como procurarei mostrar ao longo deste artigo, a conquista da legitimidade do samba foi (e ainda o é) árdua e carregada de conflitos. ${ }^{7}$ E isso porque não se pode desvinculá-la do processo de reconhecimento social do negro no Brasil. No final do século XIX, a abolição da escravidão pôs fim às antigas relações senhoriais de domínio. Com a ampliação da cidadania para os ex-escravos, a temperatura da tensão racial entre negros e brancos tende a se elevar. Como lembra Lilia Schwarcz (1993), é exatamente nesse momento, quando a igualdade jurídica é conferida a todos, que as teorias deterministas raciais ganham força no país e, ao estabelecerem distinções biológicas e hereditárias entre negros e brancos, acabam por naturalizar a diferença entre as raças. Nesse sentido, é a perfectibilidade da imensa massa de ex-escravos que estava sendo posta em questão na fundação do novo pacto político republicano, cujos termos estavam sendo então estabelecidos.

O aprofundamento da análise do debate científico da época sobre a questão racial está ausente na análise de Vianna. Ainda que, como afirma o autor, tenha havido, aos poucos, uma positivação do elemento mestiço no país, não se pode ignorar que, desde as últimas décadas do século XIX até o princípio do século XX, predominava um modelo racial de análise que via na miscigenação um sinal de degeneração.

Um caminho para o aperfeiçoamento da raça negra foi apontado pela chamada "teoria do branqueamento". Adeptos do darwinismo social, seus propositores propugnarão pelo branqueamento da população brasileira a ser obtido através de um processo gradativo de seleção natural e social, que conduziria a uma "mestiçagem eugênica”, isto é, à depuração das características negras dos mestiços.

O "homem de ciência" João Batista de Lacerda, diretor do Museu Nacional, convicto das idéias do evolucionismo social, foi o representante oficial no Primeiro Congresso Universal das Raças, realizado em Londres, em 1911, onde apresentou seu ensaio "Sur les métis au Brésil". Ele participou do Congresso com a intenção de defender a tese do branqueamento da raça - a ser atingido por intermédio da mestiçagem - como forma de resolução do "problema racial brasileiro".

Contudo, é interessante notar que Lacerda atuava como porta-voz do presidente Hermes da Fonseca (1910-14), o mesmo que, no ambiente mais intimista e privado do palácio presidencial, recebera o rancho carnavalesco Ameno Resedá e cuja mulher tocou ao violão o corta-jaca de Chiquinha Gonzaga numa recepção a 
estrangeiros. Era também o mesmo que comparecera à casa da tia Ciata - um dos redutos do samba carioca na Primeira República para divertir-se nas festas que ocorriam nesse recinto reservado. Mas também era o mesmo que, publicamente, proibira a execução do maxixe pelas bandas militares. Ao que tudo indica, parece que a boa imagem pública não combinava com "africanismos", reservando-se os apreços por essas manifestações negras para as ocasiōes em que era possível ficar-se entre quatro paredes.

A posição equívoca das elites em relação às tradições culturais negras aparece aqui com clareza. As relações íntimas que se desenvolveram entre senhores brancos e escravos negros no espaço reservado da casa-grande, deram origem a uma gama de laços pessoais. Após a Abolição, esse passado de contatos interétnicos continua a agir, ainda que restrito à esfera privada. E isso porque, no espaço público da Primeira República, essas relações não podem ser valorizadas, pois isso corresponderia a admitir negros e mestiços como atores desse mesmo espaço.

Parece portanto que, tanto no caso do samba, quanto no da capoeira ${ }^{8}$ e das religiões afro-brasileiras, ' não há oposição absoluta entre os personagens da trama. Isso nos revela algo sobre a peculiaridade das relações raciais vigentes no Brasil. Nesse sentido, enseja-se um modo de sociabilidade específico que supõe uma cumplicidade entre os círculos eruditos e populares, implicando uma circularidade cultural movida pela contínua domesticação da herança negra e africanização da herança branca.

Em um breve artigo publicado em 1982, Peter Fry (2001) analisou a maneira pela qual o samba e o candomblé, dois itens originalmente elaborados pelos negros sob dominação, teriam sido posteriormente apropriados pelos produtores de símbolos nacionais e da cultura de massas. Na ocasião, o autor interpretou essa conversão de símbolos étnicos em nacionais como uma estratégia política para acobertar e mascarar a dominação racial, dificultando inclusive a sua própria denúncia. Em outro artigo, publicado após 25 anos, Fry (2001) reviu suas conclusões - inclusive citando Vianna (1995) entre os responsáveis por isso - afirmando que a sociedade brasileira não pode ser pensada como sendo formada por "dois atores coletivos estanques (elite/povo ou brancos/negros)" (p. 50). Isso ocorreria porque no Brasil, cuja herança colonial portuguesa tem como marca uma lógica de assimilação, "os candomblés, macumbas e espiritismos contemporâneos são o precipitado de embates e negociaçôes entre elite e povo, brancos e negros, letrados e iletrados [...] ao longo dos anos". Considerando que o ra- 
cismo não deixou de estar oculto nem de ser denunciado no Brasil, Fry aponta que sua opinião hoje é de que "o Brasil vive em constante tensão entre os ideais da mistura e do não-racialismo [...] por um lado, e as velhas hierarquias raciais que datam do século XIX, de outro" (pp. 50-52).

Se é certo que temos no Brasil um "modo múltiplo" de classificação racial, diferente do "modo binário" norte-americano (Fry, 1995-96), cuja colonização anglo-saxã deu origem a uma lógica segregacionista, não podemos, contudo, deixar de lado a discussão acerca da cultura do poder, substituindo-a por uma ênfase demasiada no poder da cultura como, me parece, faz Vianna (1995), relevando a importância do contexto sociopolítico da Primeira República e dos conflitos sociais do período.

Vários estudiosos, em busca de nossas especificidades locais, já apontaram para a promiscuidade entre os domínios da ordem e da desordem no Brasil, o que adviria de uma indefinição das fronteiras entre o espaço público e o privado, fruto de uma sociedade altamente hierarquizada e autoritária."

Antônio Candido (1970) ressaltou a imprecisão das fronteiras entre o público e o privado no país, apontando para um dos "princípios constitutivos da sociedade brasileira" que chamou de "dialética da malandragem", responsável pela interação recíproca do universo da ordem com o da desordem no país. Analisando a obra Memórias de um Sargento de Milícias, de Manuel Antônio de Almeida (escrita entre 1852 e 1853), Candido tenta estabelecer uma simbologia do nacional através da figura do malandro, o qual transitaria, com grande dose de sabedoria política, entre os espaços pouco delimitados do lícito e do ilícito. A dialética da ordem e da desordem, salienta o autor, é o princípio estrutural que ordena o sistema de referência das relações humanas do livro.

Parece-me que o sabor especial do samba Pelo Telefone (ao qual voltarei adiante), primeiro samba gravado e que obteve grande repercussão na época está, justamente, na denúncia cínica e brincalhona do conluio entre a ordem e a desordem, o que corrobora a proposição de Antônio Candido sobre a presença da ética da "dialética da malandragem" na sociedade brasileira.

Assim, além da ausência do aprofundamento sobre o debate da questão racial, falta também ao trabalho de Vianna (1995) uma maior contextualização do embate político que a nascente República brasileira travou para obter sua legitimação. Dessa forma, para continuarmos na pista do deslindamento do "mistério do 
samba", interessa também recuperar um outro debate acerca da natureza e sobretudo da legitimidade do novo regime.

A República que se instaura no país a partir de 1889, refratária à participação política da imensa maioria da população e às suas manifestações culturais, não consegue, efetivamente, republicanizar o país (Carvalho, 1987:161-4). Se, por um lado, o desencanto com a República, no interior das próprias elites políticas, tornava-se evidente ("essa não é a república dos meus sonhos", lamentavam-se alguns descontentes), por outro lado, as classes populares não se reconheciam naquela nação que as confinava, a elas e a sua cultura, a suas "malocas".

Entretanto, para garantir respaldo popular, o regime procurou criar em torno de si uma simbologia. Como mostra José Murilo de Carvalho, o modelo europeu de cidadania que a República persegue a levará a inspirar-se na França para a formação de um imaginário popular. Embora conclua pelo fracasso da tentativa de implantação de uma simbologia republicana, Carvalho realça que as duas únicas tentativas bem-sucedidas foram aquelas em que as autoridades souberam ceder lugar à tradição: no caso do hino ("única vitória popular no novo regime"), herdado do Império, e da bandeira, também inspirada em sua antecessora monárquica. Ou seja, o hino e a bandeira vingaram como símbolos republicanos enquanto reelaboração de símbolos monárquicos (Carvalho, 1990:109-128).

Porém, nessa mesma República podemos observar a existência de grupos e agremiações populares que faziam política a seu modo, ainda que distantes dos canais oficiais de participação (Carvalho, 1987). Um exemplo disso era a Festa da Penha que, como conclui Rachel Soihet (1998:41), após acompanhar detidamente a história da mesma, "tornou-se a festividade mais popular do Rio de Janeiro depois do Carnaval”. A grande concentração de grupos musicais, cordóes, ranchos e blocos carnavalescos e o entusiasmo popular fariam desta festa uma preliminar das folias de Momo. Alguns que, posteriormente, seriam consagrados como expoentes da música popular brasileira eram seus assíduos freqüentadores, como Sinhô, Heitor dos Prazeres, Pixinguinha, Caninha, João da Baiana e Donga.

Além disso, havia ainda as agremiações carnavalescas. Em sua análise sobre o carnaval carioca entre 1880 e 1920, Maria Clementina Pereira da Cunha (2001), evitando uma abordagem evolucionista do assunto, aponta para o carnaval multifacetado que tomava conta das ruas do Rio de Janeiro desde meados do século 
XIX. Como mostra a autora, ainda que fosse o modelo "civilizado" do carnaval europeu que se desejasse impor, outras formas populares de folia conviviam com as Grandes Sociedades Carnavalescas desde meados do século XIX e até nelas se inspiravam para organizar seus desfiles, apropriando-se de alguns elementos, mas atribuindo-lhes significações distintas.

Em outro estudo relacionado à multiplicidade de formas de se brincar o zé-pereira durante o carnaval carioca entre as últimas décadas do século XIX e princípios do século XX, Cunha (2002) chama atenção para os perigos de uma leitura presentista para o Carnaval. Suas críticas recaem sobre boa parte da historiografia brasileira relativa ao tema (pp. 383-88) que, ao permanecer no nível do discurso de parte da intelectualidade carioca de princípios do século XX, a qual via na festa de Momo uma marca de brasilidade, acabou por fazer, de forma anacrônica, da história do carnaval "[...] um simulacro da história de uma identidade construída e atribuída à nação [...]" (p. 386). Segundo a autora, construiu-se uma história política linear e etapista para o carnaval brasileiro, sendo este abordado como uma síntese sincrética e festiva da miscigenação racial.

Nesse sentido, Cunha, acertadamente, sugere que, mais profícuo do que ver no carnaval uma festa unívoca e nacional, é procurar ver o que fez dele "um colorido campo de batalha", quer dizer, "[...] manifestação de conflitos em torno de normas e padrões de comportamento, de disputa pela legitimidade da presença de diferentes setores e grupos no interior da festa, em um tenso diálogo social" (ibidem:388).

Assim, devemos ter cuidado para não incorrermos em um anacronismo cultural ao atribuirmos ao samba um sentido de ícone representativo da brasilidade em um momento no qual vários ritmos eram apreciados.

Deve-se atentar inicialmente para a indeterminação do momento histórico vivido pela música popular brasileira das primeiras décadas do século XX. Nos anos 1910 e 1920, observa-se no Rio de Janeiro uma profusão de ritmos nacionais e internacionais: maxixe, tango, tango argentino, tango carnavalesco, toada sertaneja, batuque, embolada, valsa, mazurca, xote, samba, samba carnavalesco, lundu, corta-jaca, marcha carnavalesca, charleston, one step, fox-trot, rag-time, cateretê, samba-canção, choro, choromodinha, choro-canção, modinha, toada, marcha, marcha-rancho, dentre outros. 
Entre os ritmos nacionais, parecem predominar os sertanejos, ${ }^{12}$ o choro e as variações rítmicas do samba (aliás, nesse momento há ainda uma indefinição em torno da designação "samba", usada para indicar um certo ritmo de origem rural ou urbana, mas também para designar festa ou dança). Na verdade, embora disputem a primazia em relação à preferência dos ouvintes, não há uma oposição entre esses gêneros. João Pernambuco, por exemplo, além dos ritmos nordestinos, compunha também sambas e batuques e, inclusive, sua canção Cabocla de Caxangá (em parceria com Catulo da Paixão Cearense), que divertiu o público no carnaval de 1914, foi gravada sob o rótulo de "batuque sertanejo". Inspirados nessa canção, os que mais tarde ficariam famosos como os 8 Batutas - cujo repertório era formado por choros, sambas, toadas, valsas e outros ritmos, tendo em sua formação músicos populares que se tornariam célebres como Pixinguinha e Donga - formaram o Grupo de Caxangá, apresentando-se vestidos em trajes nordestinos.

Se o samba foi, ao longo das três primeiras décadas deste século, conquistando paulatinamente o gosto musical de uma significativa parcela da população brasileira, seu significado não era o mesmo para todos. A visita oficial do casal real da Bélgica ao Rio de Janeiro, em 1920, por exemplo, é um episódio que nos revela como esse ritmo servia tanto para que as elites expressassem a imagem que queriam construir para o Brasil, como também para que as classes populares o fizessem a sua maneira. Assim, supostamente por evocarem a brasilidade com sua música, os 8 Batutas serão convidados a apresentar-se para tocar durante o almoço oferecido ao rei Albert e à rainha Elizabeth da Bélgica no palácio presidencial. Mas os Batutas também aproveitaram o mesmo evento para dar suas arranhadas naquela imagem idílica do Brasil das elites. Em 1921, montaram a revista O que o Rei não Viu. Arranjada pelos dois irmãos Pixinguinha, China e por Dias Pinto, seu título tinha um duplo alvo: referia-se ao mesmo tempo ao músico Sinhô, desafeto dos dois irmãos, e também troçava com a visita do par real belga ao Rio de Janeiro, pois naquela ocasião as autoridades, com a intenção de causar uma boa impressão, empenharam-se na limpeza urbana e, arbitrariamente, efetuaram inúmeras prisóes preventivas (Ruiz, 1984:24-25).

Este samba polifônico seria amplificado pelos recursos audiovisuais que a nascente cultura de massas introduzira - a gravação de discos, a introdução do rádio, a difusão do teatro de revista e a abertura das primeiras salas de cinema, como o cine Palais, no Rio de Ja- 
neiro (aí os músicos apresentavam-se antes e durante a exibição de filmes) ${ }^{13}$ - resultado de uma árdua negociação entre músicos populares e gravadoras, cantores de sucesso provenientes das classes médias, empresários teatrais, membros da elite e intelectuais.

O desafio que permanece, me parece, é explicar o "mistério do samba", isto é, por que dentre todos os ritmos populares da época, será o samba aquele que se tornará, paulatinamente, o ritmo nacional por excelência. Não pretendo aqui, evidentemente, esgotar o assunto, que ainda requer muito estudo, mas apenas sugerir uma interpretação que contribua para perscrutar esse "mistério" que permanece praticamente insondável, ainda que Vianna (1995) tenha se esforçado em "decifrá-lo".

\section{"Pelo telefone": a indústria fonográfica amplifica a voz do samba}

Uma das grandes novidades daquele começo de século foi a gravação de discos. A Casa Édison, cuja matriz era norte-americana, foi pioneira no ramo das gravadoras no Brasil e instalou-se no Rio de Janeiro em 1900. Aos poucos, outras gravadoras viriam para a capital federal, dentre as quais: Columbia Phonograph, Victor Record, Favorite Record, Grand Record Brasil, Odeon, Parlophon, Brunswick, Discos Phoenix e Discos Gaúcho (Cabral, 1996b: 8, 18-19).

Em 1916 foi feita a gravação do samba Pelo Telefone. A canção saiu pela Casa Édison, na voz do cantor Baiano, no final de 1916, com a finalidade de lançá-la para o carnaval que se aproximava. Foi registrada na Biblioteca Nacional, em dezembro daquele mesmo ano, como samba carnavalesco, com música de autoria de Donga e letra do jornalista Mauro de Almeida (Peru dos Pés Frios).

O retumbante sucesso do Pelo Telefone fez dele um divisor de águas na música popular brasileira. ${ }^{14} \mathrm{O}$ tema central da canção é certamente um dos fatores que mais concorreram para essa grande repercussão. Trata-se de uma sátira à cumplicidade entre um delegado da polícia e o jogo ilícito, cuja denúncia, aliás, era recorrente na cidade do Rio de Janeiro.

É significativo que a temática do primeiro samba a estourar nas paradas de sucesso tenha sido a revelação dessa aliança espúria que aponta para o conluio entre a ordem e a desordem. No caso da perseguição ao samba, por exemplo, apesar da truculência ser a tônica da atuação policial da época em relação aos sambistas, um de- 
poimento de Donga deixa entrever uma certa cumplicidade entre estes e os policiais, os quais, vale lembrar, tinham muitas vezes a mesma origem social. Inicialmente, o artista recorda-se de ocasiōes em que "festas íntimas", realizadas nas residências, eram bruscamente interrompidas por policiais que levavam os moradores ao distrito para dar explicações "por estar dançando samba, este que [hoje] toda gente admira e dança”. Mas, em seguida, o compositor lamenta a "falta de sorte dos sambistas", quando a abordagem era efetuada por policiais menos tolerantes para com o samba e seus instrumentos de acompanhamento: "Na Festa da Penha, os pandeiros eram arrebatados pela polícia, por medida de precaução, quando por falta de sorte dos sambistas, não estava de serviço na Penha, o piquete da cavalaria do $1^{\circ}$ ou $9^{\circ}$ regimentos [... que sempre nos protegeu" (apud Moura, 1983:73).

Observe-se também nesse relato a súbita interrupção das "festas íntimas" pela polícia, o que revela como o espaço privado das classes populares era continuamente violado. Aliás, os sambas A Polícia já foi lá em Casa (Olegário Mariano e Júlio Cristobal), de 1929, e Se a Polícia Deixasse (Rafael Mujica e Martinez Grau), de 1927, denunciam em seu título, ainda que de forma divertida, a mesma arbitrariedade. Dessa forma, as normas de cidadania que a República introduzira e o alargamento da dimensão individual que a modernidade impunha, ao mesmo tempo que ampliavam o espaço privado das elites, restringiam aquele dos despossuídos (Sevcenko, 1998b:543-44).

Foi também a apreensão de um pandeiro na famosa Festa da Penha que deu origem a uma passagem reveladora dessa mesma imbricação entre a ordem e a desordem. Nela estiveram envolvidos o afamado sambista João da Baiana, filho de baianos, e, nada mais nada menos do que o caudilho gaúcho senador Pinheiro Machado, um dos políticos mais influentes da República Velha. Quem narra o episódio é o próprio João da Baiana:

A polícia perseguia a gente. Eu ia tocar pandeiro na festa da Penha e a polícia me tomava o instrumento [...] Houve uma festa no Morro da Graça, no palacete do (senador) Pinheiro Machado e eu não fui. Pinheiro Machado perguntou então pelo "rapaz do pandeiro". Ele se dava com os meus avós, que eram da maçonaria. Irineu Machado, Pinheiro Machado, marechal Hermes, coronel Costa, todos viviam nas casas das baianas. Pinheiro Machado achou um absurdo e mandou um recado para que eu fosse falar com ele no Senado. E eu fui [...] Ele então perguntou por que eu não fora à casa dele e respondi que não tinha aparecido porque a polícia havia apreendido o meu pandeiro na festa da Penha. Depois, quis saber se eu tinha brigado e onde se poderia mandar fazer outro pandeiro. 
"O que o rei não viu”: música popular e nacionalidade no Rio de Janeiro...

Esclareci que só tinha a casa do seu Oscar, o Cavaquinho de Ouro, na Rua da Carioca. Pinheiro pegou um pedaço de papel e escreveu uma ordem para seu Oscar fazer um pandeiro com a seguinte dedicatória: "A minha admiração, João da Baiana. Pinheiro Machado”. (Cabral, 1996a:27-8)

Este depoimento revela a presença de figuras ilustres da época, entre elas um presidente da República, marechal Hermes da Fonseca (1910-14), e seu aliado político, o senador Pinheiro Machado, na casa das "tias" baianas. Também um outro presidente do país, Venceslau Brás (1914-18), ficara muito grato à tia Ciata por tê-lo curado de um ferimento na perna por intermédio de rituais religiosos afro-brasileiros.

Mas esse episódio também evidencia algo fundamental. Ao mandar fazer o pandeiro com seu nome inscrito, o senador da República estava, por certo, procurando intimidar o policial que eventualmente fosse tentar apreender o instrumento. Porém, a pergunta inicial de Pinheiro Machado a João da Baiana ("quis saber se eu tinha brigado") sugere que, mesmo para ele, o samba "ao ar livre", isto é, enquanto manifestação pública, era passível de repressão, o que não ocorreria com o samba tocado e dançado em espaços privados (como o de seu palacete ou o da casa da tia Ciata, por exemplo).

Dessa maneira, na intimidade das casas das "tias" baianas (sendo a mais afamada a da Ciata), os dois Rios de Janeiro (o "Rio da Regeneração" e o "Rio das malocas"), separados no espaço, encontram-se num ambiente festivo, devocional ou não. Ali, mundos sociais distintos se interpenetram. Cidadãos pobres, como João da Baiana que, na qualidade de artista freqüenta o palacete de Pinheiro Machado, adentram através de sua arte, e ainda que parcialmente, a privacidade do lar dos mais ricos (Sevcenko, 1998b: 544-45). Aí estabeleciam-se alianças e obtinham-se favores.

Voltando ao samba Pelo Telefone, provavelmente para evitar dissabores, não foi a versão original - na qual a pilhéria era usada como recurso para a desmoralização de uma autoridade pública aquela apresentada oficialmente pelos autores para registro musical, mas ela circulou de boca em boca, sendo até hoje lembrada. $\mathrm{Na}$ versão registrada, o "chefe da polícia", transfigurado em rei Momo, vira o "chefe da folia" e são homenageados os carnavalescos Peru do Pés Frios (co-autor da música) e Morcego, ambos da sociedade carnavalesca Clube dos Democráticos.

Apresento em seguida as duas versões. A versão não registrada é a seguinte: 
O chefe de polícia/ Pelo telefone/ Mandou avisar/ Que na Carioca/ Tem uma roleta/ Para se jogar. I.Ai, ai, ai/ O chefe gosta da roleta/ Ó maninha/ Ai, ai ai/ Ninguém mais fica forreta/ É maninha/ Chefe Aurelino/ Sinhô, sinhô/ É bom menino/ Sinhô, sinhô/ Pra se jogar/ Sinhô, sinhô/ De todo jeito/ Sinhô, sinhô/ O bacará/ Sinhô, sinhô/ O pinguelim/ Sinhô, sinhô/ Tudo é assim (Moura, Roberto, 1983: 78).

A versão registrada é assim:

O chefe de folia/ Pelo telefone/ Manda avisar/ Que com alegria/ Não se questione/ Para se brincar/ Ai, ai, ai/ É deixar mágoas pra trás/É rapaz/ Ai, ai ai,/ Fica triste se és capaz/ E verás/ Tomara que tu apanhes/ Pra não tornar a fazer isso/ Tirar amores dos outros/Depois fazer seu feitiço/ Ai, ai, rolinha/ Sinhô, sinhô/ Se embaraçou/ Sinhô, sinhô/ É que a avezinha/ Sinhô, sinhô/ Nunca sambou/ Sinhô, sinhô/ Porque esse samba/ Sinhô, sinhô/ De arrepiar/ Sinhô, sinhô/ Põe perna bamba/ Sinhô, sinhô/ Mas faz gozar/ Sinhô, sinhô/ O "Peru" me disse/ Se o "Morcego" visse/ Eu fazer tolice/ Que eu então saísse/ Dessa esquisitice/ De disse que não disse/ Ai, ai, ai/ Aí está o canto ideal/ Triunfal/ Viva o nosso Carnaval/ Sem rival/ Se quem tira amor dos outros/ Por Deus fosse castigado/ O mundo estava vazio/ E o inferno só habitado/ Queres ou não/ Sinhô, sinhô/ Vir pro cordão/ Sinhô, sinhô/ Do coração/ Sinhô, sinhô/ Por este samba (Moura, 1983:79).

O popular ritmo amaxixado do samba também contribuiu para a sua rápida aceitação. Além disso, o refrão da música continha alguns versos retirados de uma canção folclórica nordestina apresentada numa revista de sucesso, encenada em 1916 no teatro São José.

Porém, a autoria do samba Pelo telefone é controvertida. Ainda quando o samba estava recém-lançado, na véspera do carnaval de 1917, sairia no jornal uma nota, assinada pelo Grêmio Fala Gente, anunciando que seria cantado na Avenida Rio Branco o "verdadeiro tango Pelo telefone, dos inspirados carnavalescos João da Mata, mestre Germano, nossa velha amiguinha Ciata e o inesquecível bom Hilário; arranjo exclusivamente do querido pianista J. Silva (Sinhô), dedicado ao bom e lembrado amigo Mauro, repórter da Rua, em 6 de agosto de 1916, dando ele o nome de Roceiro" (Alencar, 1980:119). Reproduzia-se então a letra da cantiga que ironizava a apropriação da mesma por Donga, também participante das rodas de partido alto e que, segundo as pessoas citadas na nota, todas bastante reconhecidas no meio negro, teria agido de forma oportunista ao registrá-la em seu nome (em relação a Mauro, autor da letra, não havia qualquer contestação): 
"O que o rei não viu”: música popular e nacionalidade no Rio de Janeiro...

Pelo telefone/ A minha boa gente/ Mandou me avisar/ Que o meu bom arranjo/ Era oferecido/ Para se cantar/ Ai, ai, ai/ Leve a mão à consciência/ Meu bem/ Ai, ai, ai/ Mas por que tanta presença, meu bem?/ Ó que caradura/ De dizer nas rodas/ Que este arranjo é teu!/ É do bom Hilário/ E da velha Ciata/ Que o Sinhô escreveu/ Tomara que tu apanhes/ Pra não tornar a fazer isso/ Escrever o que é dos outros/ Sem olhar o compromisso (Alencar, 1981:26).

De fato, é aceito pelos estudiosos da música popular que a canção teria sido composta nas rodas de samba da casa da tia Ciata, uma espécie de embaixada do samba da "pequena África" do Rio de Janeiro em princípios do século. Migrante baiana, tia Ciata (Hilária Batista de Almeida) veio para o Rio em 1876, tendo se casado com o baiano João Batista, que trabalhou como linotipista no Jornal do Commercio e posteriormente em várias funções no serviço público, inclusive numa delegacia de polícia, cargo obtido por influência do presidente da República, Venceslau Brás, como gratidão por uma cura espiritual que, como já vimos, obtivera de Ciata.

Ciata era sacerdotisa do candomblé de João Alabá e em sua casa realizava também cerimônias religiosas e lúdicas. Além disso, era quituteira e ainda costurava fantasias de baianas para o carnaval e o teatro de revistas. A atividade profissional do marido de $\mathrm{Ci}$ ata, a crescente ascendência que ela própria foi ganhando no meio negro, além da presença de pessoas influentes nas festas, garantem uma certa "imunidade" ao local que marcaria a memória cultural negra da cidade.

Os protestos dos co-autores de Pelo Telefone, bem como a apropriação indevida da música por Donga, testemunham uma nova ética que se impunha aos músicos populares e a que o sambista Sinhô (o mesmo, aliás, cuja co-autoria em Pelo telefone havia sido omitida) definiria de forma lírica: "samba é como passarinho, é de quem pegar” (Alencar, 1981:67). O nascente e promissor mercado fonográfico, trazido pelos novos ventos da modernidade, introduziu mudanças. A antiga criação coletiva e improvisada das rodas de partido alto tinha que conviver agora com a projeção de valores individuais que a profissionalização do samba possibilitava. As acusações mútuas de plágios eram constantes. O próprio Sinhô foi por mais de uma vez acusado de plagiário por Hilário Jovino, um de seus parceiros em Pelo telefone, e Heitor dos Prazeres, que, gozando da alcunha de "rei do samba" dedicada ao grande compositor, escreveu uma canção intitulada Rei dos Meus Sambas. 
Para auxiliar na difusão de seus discos, as gravadoras contariam nos anos 20 com o rádio que, no entanto, se tornaria seu forte aliado apenas a partir dos anos 30. Em 1922 foi transmitida do Rio de Janeiro a primeira emissão radiofônica. Entretanto, as deficiências técnicas relativas à transmissão, difusão, programação ou mesmo emissão do sinal adiariam por cerca de dez anos o grande impacto que esse potente veículo de comunicação teria na transformação da cultura brasileira (Sevcenko, 1998b:587-88).

Velhas rivalidades são então acionadas em razão do novo tipo de relação social que a modernidade inaugurara, como uma antiga disputa regional entre cariocas e baianos residentes no Rio de Janeiro em torno da autenticidade do samba. O berço do samba seria o Rio de Janeiro ou a Bahia? Como sabemos, essa discussão acerca da "pureza" da cultura é sobretudo política, produto do embate de grupos sociais e, nesse sentido, como ensina Eric Hobsbawm (1984), as tradições serão sempre, de certa forma e em diferentes gradações, inventadas.

É em torno dessa autenticidade ou "pureza" do samba baiano e carioca que se cria uma polêmica musical deliciosa. Ela se estendeu de 1917 a 1921, opondo, de um lado, o carioca Sinhô e, de outro, o baiano Hilário Jovino Ferreira (o "bom Hilário") e os cariocas descendentes de baianos Donga e João da Baiana, além de outros que lhes emprestaram solidariedade como Pixinguinha e China. Além do gosto pela provocação, um traço característico de Sinhô, outros motivos desencadearam a briga musical. Parece que Sinhô rivalizava com os baianos nas rodas da casa da tia Ciata e também havia se indisposto com Pixinguinha e seu irmão China quando reivindicou para si a autoria do arranjo Pelo Telefone. A polêmica é longa e envolve muitas canções e, por isso, retirarei destas apenas os trechos que interessam para o debate que faço aqui.

Sinhô, em A Bahia é Boa Terra (ou Quem são Eles), sucesso do carnaval de 1918, ironiza a Bahia, o que fica patente logo nos primeiros versos: "A Bahia é boa terra/ Ela lá e eu aqui, Iaiá/ Ai, ai, ai".

Parece que a letra fazia alusão a uma briga política baiana daquele momento, mas, por extensão, dirigia-se aos baianos de um modo geral. Estes, por sua vez, entendem o recado. O "bom Hilário" devolve com o samba Não És Tão Falado Assim, e Donga arremata com Fica Calmo que Aparece. Porém, a resposta mais veemente foi dada por Pixinguinha e China no samba Já Te Digo, de 1919, em que aproveitavam para achincalhar não só com a qualidade musical, mas também com o aspecto físico de Sinhô (eles 
eram velhos conhecidos, pois Sinhô havia sido hóspede da Pensão Viana, propriedade dos pais dos autores da cantiga):

Um sou eu/ E o outro eu já sei quem é/ Ele sofreu/ Para usar colarinho em pé/ Vocês não sabem quem é ele/ Mas eu lhes digo/ Ele é um cara feio/E fala sem receio/ E sem medo ao perigo/ Ele é alto, magro e feio/ e desdentado/ Ele fala do mundo inteiro/ No Rio de Janeiro/ No tempo em que tocava flauta/ Que desespero/ Hoje ele anda janota/ À custa dos trouxas/ Do Rio de Janeiro (Cabral, 1997: 43)

Sinhô devolve com o samba Fala meu Louro, de 1920, no qual satiriza o senador Rui Barbosa, mas novamente os baianos, de modo geral, eram o seu alvo:

A Bahia não dá mais coco/ para botar na tapioca/ para fazer o bom mingau/ para embrulhar o carioca/ Papagaio louro/ Do bico dourado/ Tu falavas tanto/ Qual a razão que vives calado?/ Não tenhas medo/ Coco de respeito/ Quem quer se fazer não pode/ Quem é bom já nasce feito. (Vasconcelos, 1985:202)

O "bom Hilário" (Hilário Jovino), acusando-o de plágio, revida a ofensa com Entregue o Samba a seus Donos, de 1920, reivindicando para os baianos a autenticidade do samba:

Entregue o samba a seus donos/É chegada a ocasião/ Lá no Norte não fazemos/ Do pandeiro, profissão/ Falsos filhos da Bahia/ que nunca pisaram lá/ que não comeram pimenta/ na moqueca e vatapá/ mandioca mais se presta/ muito mais que tapioca/ Na Bahia não tem mais coco/ É plágio de um carioca. (Alencar, 1981:33)

Sinhô, freqüentador assíduo da casa do pai-de-santo Assumano, no Rio de Janeiro, devolve a provocação no samba Sempre Voando (1921), dessa vez no campo religioso, duvidando da competência dos pais-de-santo baianos. Opõe-se aqui a "pureza" da negritude carioca à "pureza" do legado negro baiano, o que representa, acima de tudo, uma disputa política por prestígio no interior da qual inventam-se e desinventam-se tradições. Tal ironia de Sinhô é hoje absolutamente impensável devido ao grande prestígio de que gozam os pais-de-santo baianos, o que, a se julgar pela canção, naquela época não era uma "tradição": Já descobri meu bem/ Coisa que causa espanto/ $\mathrm{Na}$ Bahia tem, tem/ Gente que é pai-de-santo (Alencar, 1981:34).

Essa discussão, de certa forma, se estende até os dias de hoje. O compositor baiano Caetano Veloso, em uma canção recente, parece ter tentado colocar um ponto final na questão, elegendo a escola de samba carioca da Mangueira como o lugar "onde o samba é 
mais baiano" e lembrando as "Ciatas" que trouxeram o samba baiano para o Rio de Janeiro.

Entretanto, a discussão mais interessante não é tanto acerca da origem do samba, uma vez que as tradições servem aos grupos sociais, antes de mais nada, como um argumento político. Parece-me mais proveitoso observar aqui como o samba é uma linguagem que serve para expressar diferenças regionais, desavenças pessoais ou mesmo insatisfações populares com os poderosos. Não obstante, são evidentes as continuidades históricas entre o samba baiano e o carioca em virtude, como já vimos, não só da intensa migração baiana para a capital federal na virada do século, como também da igualmente intensa atuação dos baianos tanto nas atividades lúdicas quanto religiosas dos redutos negros da capital federal. ${ }^{15}$

\section{"A frutinha nacional": o teatro de revistas e a imagem da mulata}

Outro meio poderoso de divulgação de sambas, artistas e músicos negros nas décadas de 1910 e 1920 foi o popular teatro de revistas.

Tendo sido introduzida no Rio de Janeiro por empresários portugueses em meados do século XIX, a revista ganharia textos nacionais com Arthur Azevedo e seu parceiro Moreira Sampaio em finais do século, dupla que marcaria a história do teatro de revistas no Brasil, ${ }^{16}$ inaugurando um novo gênero teatral, a revista de ano. $\mathrm{O}$ que lhes garantiu sucesso foi o fato de que introduziram em suas peças "além das alusóes aos fatos políticos e sociais mais marcantes do ano anterior, tratados de forma satírica, e do uso sempre reiterado das alegorias como recurso de representação e observação crítica, $[\ldots]$ a caricatura explícita de personalidades públicas [...]" (Mencarelli, 1999:133).

A revista exerceu papel importante no sentido de popularização do teatro, até então restrito às camadas mais abastadas da população, que costumavam comparecer aos espetáculos montados pelas grandes companhias estrangeiras francesas e italianas.

O historiador e crítico da música popular brasileira, José Ramos Tinhorão, enfatiza a relevância do teatro de revistas para a divulgação da música e mesmo de uma dramaturgia populares:

Essa estreita ligação com o gosto de camadas cada vez mais amplas da população [...] deu origem a duas importantes conseqüências: conferiu 
"O que o rei não viu”: música popular e nacionalidade no Rio de Janeiro...

uma característica brasileira ao gênero, na base de aproveitamento de tipos populares como o matuto, o coronel-fazendeiro, o português, a mulata, o guarda, o capadócio (depois chamado malandro), o funcionário público, o camelô etc., e fez essa pequena humanidade dançar e cantar durante meio século ao som das maiores criações musicais e coreográficas do povo - o lundu, o maxixe e o samba. (Tinhorão, 1972: 21)

Conhecidos humoristas cariocas também escreveram para o teatro de revistas em princípios do século XX. Monica Pimenta Velloso, em Modernismo no Rio de Janeiro (1996), analisa a trajetória de um grupo de caricaturistas que, na virada do século XIX para o século XX, pensaram a identidade nacional através do humor e da irreverência, inspirados no cotidiano das ruas do Rio de Janeiro. Se, no Rio de Janeiro, o modernismo teve um caráter fragmentário e não se configurou em um movimento, como na capital paulista, também lá havia grupos de artistas e intelectuais preocupados com os traços definidores da identidade brasileira.

A autora destaca o intercâmbio do grupo de humoristas cariocas com alguns espaços da cultura popular. Bastos Tigre e Raul Pederneiras escrevem para o teatro de revistas, sendo este último compositor também de canções inspiradas no folclore nordestino. Além disso, acompanhados por outros intelectuais, como Emílio de Menezes, Hermes Fontes e Afonso Arinos de Mello Franco, costumavam sair para noitadas musicais junto a Donga, Pixinguinha e Heitor dos Prazeres. Também compareciam à festa da Penha, onde “improvisavam conferências e caricaturas" (1996:21-34, 43).

No período anterior ao carnaval, eram montadas as chamadas "revistas carnavalescas", que auxiliavam na difusão dos sambas. Mas, também ao longo do ano, o teatro rebolado divulgava o trabalho dos compositores populares. O extraordinário compositor Sinhô projetou-se no Rio de Janeiro por meio dele. Conhecido como o "Rei do samba", foi o maior expoente desse gênero musical nos anos 20, tanto pela quantidade quanto pela qualidade de sua produção.

Foi também o teatro de revistas que lançou a primeira grande cantora brasileira de sambas, que viria a exercer influência fundamental em cantoras das gerações seguintes, entre elas Carmen Miranda. Era Araci Cortes, a "Linda flor". Ela se autodenominava uma "mestiça terrível - filha de brasileiro com espanhol e neta de paraguaio" (Ruiz, 1984:12).

Aos poucos ela se firmará como a primeira grande intérprete de sambas e tornará célebre nos palcos a personagem da "mulata brasileira”. Como diz seu biógrafo Roberto Ruiz, referindo-se ao 
papel da cantora na criação de uma revista nacional, desvencilhada do modelo luso que lhe dera origem: "[...] foi Araci que, pode-se dizer, consolidou o tipo [da 'mulata'] e fez do samba uma força de brasilidade na marcha descolonizadora da revista" (ibidem:35). Calçando "chinelinhas de baiana", a estrela Araci se notabilizou pela sensualidade do requebrado e sapateado que marcava suas coreografias. Um dos sambas que pôs em delírio o público do teatro do Recreio em 1929, composto por Ary Barroso, foi o malicioso Samba da Gelatina, que insinuava uma analogia entre os movimentos dessa guloseima e os da "mulata":

Treme, treme/ Requebrando/ Treme, treme/ Rebolando/ Mulata vai devagar/ Com tanta malemolência/ Mulata, tenha paciência/ Pode quebrar!/ Canjica de milho verde/ Polvilhada de canela/ Tremelicando no prato/ Como sei de donzela/ Mexo, mexo, remelexo/ Requebrando meus quadris/ Ai que gelatina assim/ Juro que eu nunca fiz! (Ruiz, 1984:127)

Um grande número de sambas interpretados por Araci Cortes fazem referências às mulatas (e aos mulatos), às vezes nos próprios títulos, como por exemplo: O Choro das Mulatas, 1927; Esse Mulato Vai Ser Meu, 1930; Mulata, 1929; Mulata Revoltosa, 1931; Mulato Bamba, 1932; Preto e Branco, 1930. Apareciam também, embora em menor número, as "morenas", uma classificação racial que talvez equivalesse a de mulata. As referências às brancas são praticamente inexistentes. Contudo, nessa terra de mulatas, parecia não sobrar muito lugar para as negras também já que, como dizia um samba, lançado por Araci em 1934, Crioula Só por Necessidade.

Mas, embora Araci tenha dado maior visibilidade ao tipo da "mulata", bem antes dela ele já aparecera no teatro rebolado. Em 1906, estreava no Palace-Teatro a revista Vem cá, mulata (José do Patrocínio Filho, Chicot e Thoreau) e no teatro Carlos Gomes a revista $O$ maxixe (Costa Júnior, Paulino Sacramento e Luís Moreira), ambas tendo como música principal a canção carnavalesca daquele mesmo ano Vem cá, mulata (Arquimedes de Oliveira e Bastos Tigre). Em $O$ maxixe, a intérprete era Maria Lino, a mesma que mais tarde acompanharia Duque para dançar maxixe em Paris.

Esta canção, cantada no carnaval e na revista, obteve um estrondoso sucesso, chegando a ganhar uma versão parisiense que, em 1912, foi editada também em Berlim com o nome La maxixe brésilienne (Alencar, 1980:98-99). O estribilho famoso era o seguinte: "Vem cá, mulata!/ Não vou lá não./Sou Democrata/ de coração". Sobre este maxixe, há a passagem anedótica em que um cer- 
to marechal de guerra alemão, o ministro Von Reicheau, em visita oficial ao Brasil no ano de 1907, ao ser homenageado por uma banda militar, pediu ao maestro que tocasse alguma música brasileira. Podia ser aquela "do fem cá mulate", dizia ele, referindo-se ao sucesso carnavalesco de 1906, Vem cá, mulata!. A banda atacou o maxixe, deixando enfurecido o então ministro da Guerra, marechal Hermes da Fonseca, que determinou a proibição da execução do maxixe pelas bandas da corporação, ao menos nas solenidades oficiais (Efegê, 1974:158).

Assim, também no exterior ia aos poucos se difundindo a imagem da mulata brasileira. Alguns anos mais tarde, o músico da vanguarda artística francesa Darius Milhaud encanta-se com o samba $\mathrm{O}$ boi no telhado, e o recria, incluindo-o em suas apresentaçôes em Paris. A letra do samba alude à mulata, companheira na folia carnavalesca:

Vem mulata ter comigo/ Vamos ver o Carnaval/ Eu quero gozar contigo/ Esta festa sem rival/ Vem cá, vem cá, vem cá/ meu bem/ Como eu não há, não há/ ninguém/ Pula, pula, perereca/ E segura esta boneca/Vem cá, vem cá, vem cá (bis)/ Olá/ Segura o cabrito/O boi é bem manso/ Mulata cutuba (bis)/ Agüenta o balanço.

Seria, sobretudo, com a famosa revista Forrobodó (Carlos Bittencourt e Luís Peixoto com músicas de Chiquinha Gonzaga), montada em 1912, que a "mulata", interpretada por Cecília Porto, ganharia definitivamente a platéia. É importante notar que se, nas revistas Vem cá, mulata, O maxixe e Forrobodó, as mulatas eram interpretadas por atrizes brancas, as próximas "mulatas" que fariam sucesso nos palcos, Otília Amorim e Araci Cortes, eram, elas mesmas, mestiças.

Na revista Forrobodó, a "mulata" é cantada como uma mulher constantemente assediada, nossa "frutinha nacional", mas que podia ser fatal se ingerida:

Sou mulata brasileira/ feiticeira/ frutinha nacional/ Sou perigosa e matreira/ sou arteira/ como um pecado mortal /[...]/ Tenho sempre uns renitente/ pela frente/ mas em todos dei a lata/ Nesta terra, francamente/ minha gente/ não se pode ser mulata! (ibidem: 101)

Mas, além de servir para expressar a representação de um símbolo nacional popular, o tipo da "mulata" servia também para abordar um outro tema corriqueiro no cotidiano da cidade: as relações afetivo-sexuais interétnicas. Dessa forma, em várias composições a mestiçagem racial, principalmente entre o clássico par mu- 
lata-português, é tematizada através da figura da mulata. Na revista Diz isso Cantando (Ary Barroso, J. Cristobal, Augusto Vasseur, Luís Peixoto), estrelada por Araci Cortes em 1929, a música Boneca de Piche traz um diálogo entre um casal formado por um negro e uma mulata. Diante da constatação que ele faz sobre a atração do branco pela "fruta", ela ameaça trocá-lo por um português:

[...] Da cor do azeviche!/ Da jabuticaba!/ Boneca de piche!/ É tu que me acaba!/ Sou preto e meu gosto/ Ninguém me disputa/ Mas há muito branco/ que gosta da fruta! (bis)/ Eh! Eh!/ Tem português assim nas minhas águas!/ Que culpa eu tenho de ser boa mulata?/ Nêgo, se tu "borrece" as minhas máguas/ Eh! Eh!/ Eu te dô a lata! [...] (adaptado de Ruiz, 1984: 156-158).

Mas "mulata" podia ser também a sedutora favela, como no samba Minha Favela (Sá Pereira e Marques Porto), interpretado também por Araci Cortes na revista Pensão Meira Lima, de 1930. Nessa bela composição, a mesma favela que envergonhava o "Rio da Regeneração" era motivo de orgulho para o "Rio das malocas": Minha doce companheira/ És mulata, és brasileira/ És minha fascinação!/ Minha favela/ Tens na luz pálida, amena/ Todo cheiro da morena/ Que embriaga o coração.

Além disso, também a cor da "mulata" e sua brasilidade podiam servir como metáfora política para expressar a alternância de presidentes paulistas e mineiros durante a Primeira República, como no maxixe Café com Leite (Freire Júnior), de 1926:

Nosso mestre Cuca movimentou/ O Brasil inteiro/ Pois cada um Estado pra cá mandou/ O seu cozinheiro/ Mexeu-se a panela, fez-se a comida/ Com perfeição/ Assim foi a bóia bem escolhida/ Com perfeição/ Café paulista/ Leite mineiro (bis)/ Nacionalista/ Bem brasileiro/ É preto com branco café com leite/ Cor democrata/ É preto com branco meu bem aceite/ Cor da mulata/ O leite é bem grosso, o café é forte/ Agüenta a mão/ As novas comidas têm que dar sorte/ Na situação. (Alencar, 1980: 169-70)

Vemos assim que, nesse registro popular, o tema da mestiçagem é protagonizado pela imagem polissêmica da mulata. Mulher sedutora e objeto do desejo de negros e brancos, ela é também representante da brasilidade, nossa "fruta nacional", da política nacional do café com leite, ao mesmo tempo que é identificada com o local de moradia, a "favela mulata". Assim, lida nesta chave, a imagem da mestiçagem é difusa e a "mulata" parece funcionar como uma categoria explicativa para uma mestiçagem que é vivenciada no nível das relações pessoais do cotidiano. 
Quando a cantora negra norte-americana Josephine Baker veio ao Brasil em 1929, para se apresentar no Teatro Cassino, no Rio de Janeiro, Araci Cortes foi convidada para recepcioná-la com uma apresentação, na qualidade de "intérprete da música popular brasileira”. A artista, discriminada em seu país, imigrara para $\mathrm{Pa}$ ris, onde, acompanhada por bandas de jazz, se consagraria por toda a década de 20 como a "Vênus de Ébano", a "Cleópatra do Jazz", dançando "quase nua, envolta numa fantástica tanga, onde pencas de bananas de fantasia compunham um conjunto exótico que fascinava as ululantes multidões da capital francesa" (Ruiz, 1984:207; Sevcenko, 1998a:279). ${ }^{17}$ A sensualidade e a arte da sauvage Baker também fascinaram o público brasileiro, sendo que ela voltaria ao Brasil em mais duas outras oportunidades. Alguns anos mais tarde, em 1933, as duas cantoras se encontrariam em Paris, onde Araci Cortes, "la célèbre folkloriste brésilienne", se apresentaria na boate Chez Les Nudistes. Naquela ocasião, Araci integrava o elenco da primeira companhia teatral brasileira a ir à Europa, numa bem-sucedida temporada em Lisboa e Porto (Ruiz, 1984:172-74).

Com a concorrência do cinema falado e do rádio, o teatro de revistas perderia paulatinamente importância. Também o maxixe, seu ritmo característico, declinaria nesse período Entre alguns jovens compositores cariocas do bairro do Estácio de Sá, um novo ritmo de samba florescia, o qual, paulatinamente, se tornaria hegemônico. Esses compositores formaram o bloco carnavalesco Deixa Falar em 1928, localizado no bairro carioca do Estácio de Sá, que reuniu sambistas que inovaram na percussão, introduzindo o surdo e a cuíca. Alguns compositores que se tornariam depois famosos freqüentaram as rodas do Estácio, como Ismael Silva e Bidê. ${ }^{18}$

Porém, apesar da indefinição do termo, o samba, mais precisamente o samba carioca, surgido no caldeirão de ritmos presentes naquele começo de século, vai se firmando enquanto tal ao longo da década de 20 e, nas duas décadas posteriores, se tornará o mais legítimo representante da música popular brasileira para fora e para dentro do país.

\section{Os 8 Batutas: música nacional com ou sem aspas?}

Os 8 Batutas, conjunto musical formado por alguns que viriam a se tornar grandes figuras da música popular brasileira, se 
uniram, no ano de 1919, para tocar no elegante cinema Palais na capital federal. Compunham o conjunto: Pixinguinha, na flauta; Donga, no violão; China, no violão e canto; Nelson Alves, no cavaquinho; Raul Palmieri, no violão; Jacó Palmieri na bandola e reco-reco; José Alves de Lima (o Zezé), no bandolim e ganzá, e ainda Luis de Oliveira. O programa anunciava: "Última novidade no mundo artístico carioca, no seu admirável repertório de música vocal e instrumental brasileira. Maxixes, lundus, canções sertanejas, corta-jacas, batuques, cateretês etc" (Cabral, 1997: 45).

Ainda que seu repertório, como se pode perceber, conte com ritmos variados, os 8 Batutas contribuirão para a divulgação do samba nos anos 20, tanto para dentro como para fora do país. Apesar do virtuosismo de seus componentes, a temporada dos 8 Batutas no cinema Palais causou protestos. Evidencia-se aqui a oscilação entre a aceitação e a rejeição da música popular. Um grupo que contava com quatro negros, cantava sambas, emboladas e outros ritmos populares e vestia-se à moda sertaneja, apresentando-se num elegante cinema da capital federal, podia vir a provocar um certo incômodo.

O maestro e crítico musical Júlio Reis, em sua coluna do jornal $A$ Rua, considerou um "escândalo" a presença dos 8 Batutas naquele local. No entanto, o jornalista Xavier Pinheiro, da Revista da Semana, saiu em defesa dos "rapazes morenos", cujas composições, como as modinhas, as chulas, os sambas, os tangos e outras, todas de "cunho nacional [...] têm sido apreciadas pela nossa finíssima sociedade, não têm escandalizado, têm obtido ruidoso sucesso" (apud Cabral, 1997:46).

No entanto, essa projeção dos 8 Batutas lhes rendeu bons contatos. Convites para festas e espetáculos começaram a surgir e a Odeon gravou seis músicas do grupo naquele mesmo ano. Além disso, o magnata Arnaldo Guinle, que os ouvira tocar, encantou-se com sua música, o que teria grande importância na carreira do conjunto, pois financiaria suas viagens pelo Brasil e ao exterior. Os 8 Batutas foram chamados a participar dos saraus que organizava em sua residência e, numa certa ocasião, o "dr. Arnaldo", como se refere a ele Donga, em depoimento ao Museu da Imagem e do Som (MIS), ofereceu aos 8 Batutas a oportunidade de excursionar pelos estados de São Paulo, Minas, Bahia e Pernambuco com o propósito de divulgar seu trabalho.

Especificamente em relação à música popular se, para dentro, os ritmos oriundos das classes populares, em particular o samba, iam se firmando como a música brasileira por excelência, para 
fora também iam ganhando a fama, cada vez mais, de representantes da brasilidade. Assim, a valorização da cultura popular por certos segmentos intelectuais e artísticos não se dá apenas por um movimento para dentro do país. Há também um outro movimento de fora para dentro que aprecia as manifestaçôes populares do Brasil, em especial aquelas de raízes negras. Isso ocorre, quer por meio da vinda para o Brasil de artistas estrangeiros, ávidos por conhecê-las, quer através de brasileiros (incluindo-se aí os artistas) que parecem ter, em suas viagens ao exterior, uma revelação sobre um Brasil que lhes era praticamente desconhecido.

Como vimos, também a artista negra norte-americana Josephine Baker, em sua visita ao Brasil, manifestou seu desejo de conhecer o samba e maravilhou-se com a grande cantora brasileira de teatro de revistas Araci Cortes. Mas seriam sobretudo alguns artistas ligados à arte moderna e residentes em Paris que estabeleceriam uma relação mais estreita com a música popular brasileira. As exposições etnológicas de princípios do século em alguns museus europeus haviam possibilitado aos artistas travar contato com a arte negra e indígena. A tendência cubista na pintura, inaugurada por Picasso e Braque, e na poesia, encabeçada por Blaise Cendrars e Apolinnaire, seria tributária dessa arte não-ocidental.

O exímio músico francês Darius Milhaud, afinado com a vanguarda artística parisiense, residiu no Rio de Janeiro entre 1917 e 1919 a serviço da embaixada da França. Interessado pelos temas e ritmos populares, travou relaçóes com o meio musical carioca. Inspirado no maxixe O Boi no Telhado, de Zé Boiadero (José Monteiro), lançado no carnaval de 1918, compóe a suíte Le Boeuf sur le Toit e a divulga em Paris no ano seguinte. Lá, funda, junto com Jean Cocteau, o jazz-cabaré O Boi no Telhado, cujo nome fora retirado de um balé de autoria dos dois artistas, inspirado no maxixe acima mencionado (Sevcenko, 1998a:201).

Blaise Cendrars também esteve no Brasil (por mais de uma vez), subvencionado pelo milionário e mecenas paulista Paulo Prado. Em sua estadia de 1924, quando permaneceu por nove meses, travou contato com artistas modernistas em São Paulo e com músicos populares no Rio de Janeiro, assistiu ao carnaval do Rio de Janeiro (aí conheceu Donga e, inusitadamente, subiu sozinho o Morro da Favela), passando a semana santa nas cidades históricas de Minas Gerais. Essa viagem contou também com a presença de importantes artistas brasileiros, como Mário de Andrade, Tarsila do Amaral e Oswald de Andrade, dentre outros, sendo por todos batizada como a "redescoberta-do-Brasil". 
Contudo, se a crítica aos 8 Batutas era bastante unânime em apontar-lhes como legítimos representantes da nacionalidade brasileira quando excursionavam pelo Brasil afora, este consenso desaparece quando, em 1922, a trupe, financiada pelo mesmo Arnaldo Guinle, vai a Paris para uma temporada no elegante cabaré Sheherazade. Essa casa era dirigida pelo brasileiro Duque, que se notabilizara no exterior com seus passos de maxixe.

O maxixe atingiu seu auge entre o começo do século e meados da década de 20. Tratado pela imprensa como "dança nacional", foi bastante difundido, inclusive para além dos "assustados" (bailes) dos bairros negros, penetrando também entre as camadas mais abastadas.

Entretanto, o maxixe provocou protestos moralistas por parte de autoridades civis e eclesiásticas devido a sua volúpia e lascívia, pois os casais requebravam-se, dançando colados um ao outro todo o tempo. Porém, a reação vem através da galhofa. Muitas cançôes tratavam irreverentemente as censuras à dança, como em Maxixe Aristocrático (1904, José Nunes): O maxixe tem ciência/ ou pelo menos tem arte/ Para haver proficiência/ basta mexer certa parte/ Pois o próprio Padre Santo/ sabendo o gosto que tem/ virá de Roma ao Brasil/ dançar maxixe também (Efegê, 1974:80-81).

O papa não veio ao Brasil, mas o maxixeiro Duque foi à Europa. Desistindo da profissão de dentista, chegou em Paris em 1912, acompanhado por sua primeira partenaire, a atriz de revistas Maria Lina. Numa de suas vindas ao Brasil, Duque dançou com outras de suas partenaires, a francesa Gaby, ao som dos 8 Batutas, no chique Assírio (situado no subsolo do Teatro Municipal do Rio de Janeiro). Acompanhado de seu amigo, o mesmo Arnaldo Guinle, convenceu-o a bancar a viagem do grupo "para divulgar o samba e outros ritmos brasileiros, como [ele] já o fizera com relação ao maxixe" (Vasconcelos, 1985: 76).

Devido a uma súbita mudança na composição do grupo, os Batutas viajaram para Paris como Les Batutas ou L'Orchestre des Batutas. A crítica se dividiu quanto à representatividade dos músicos enquanto porta-vozes da "música nacional" e também no que se refere à imagem que os músicos, muitos do quais negros, passariam dos brasileiros. Um articulista deplorava o fato de que fosse mostrado nos boulevards de Paris "um Brasil pernóstico, negróide e ridículo" (Diário de Pernambuco, 1.2.1922 apud Efegê, 1985:183), enquanto outro, endossando esta opinião, acrescentava: "são oito, aliás, nove pardavascos que tocam viola, pandeiro e outros instrumentos rudimentares [...] E depois ainda nos queixa- 
mos quando chega por aqui um maroto estrangeiro que, de volta, se dá à divertida tarefa de contar das serpentes e da pretalhada que viu no Brasil" (Jornal do Comércio, Recife, 1.2.1922 apud Cabral, 1997:73-4).

Também condenava-se que essa "pretalhada" com seus "instrumentos rudimentares" estivesse mostrando a música brasileira. Um cronista, estarrecido com isso, estabeleceu uma diferença entre a "nossa música", "que só mesmo entre aspas poderia ser adaptada àquela da corporação [os Batutas]", e a "música nacional (sem aspas)". Ele considera que, quando se trata de mostrar no exterior "nossa cultura nacional", "os maxixes tocados pelos 8 Batutas não podem dar a mínima idéia do nosso adiantamento em um terreno em que, incontestavelmente, temos alcançado um desenvolvimento notabilíssimo".

Quais eram então os exemplos de música nacional? Para o autor do artigo, os parisienses deveriam estar ouvindo, por exemplo, a Sertaneja (uma peça de 1869, composta para piano solo sobre o tema Balaio meu bem balaio), do pianista Itiberê da Cunha - considerado um dos precursores da introdução de tema folclóricos na música brasileira —, ou a Habanera, de Arthur Napoleão, ambos músicos de formação erudita. Certamente, emendava ele desqualificando os Batutas, seriam vistos ironicamente pelos franceses como um grupo exótico: “[...] É como se aparecesse na Avenida Rio Branco, à hora de grande movimento, um grupo de africanos a chamar a atenção com uns chocalhos e outros apetrechos com que costumam sambar em seu país" (Gazeta de Notícias, RJ, apud Cabral, 1997:78-9).

Entretanto, alguns jornalistas saíam em defesa do grupo. Argumentava-se que eram "uma das expressões mais legítimas do que é nosso" (A Pátria, 28.1.1922 apud Cabral, 1997:72). Benjamim Costalat lembra que, quando os exímios Batutas despontaram, despertaram a inveja de muitos e "começaram os despeitados a alegar a cor dos 8 Batutas, na maioria pretos. Tranqüilizando os que temiam pela boa imagem do país, menciona a singeleza e a "pureza" do grupo, assegurando que "[...] os 8 Batutas não desmoralizarão o Brasil [...] Levarão a verdadeira música brasileira, essa que ainda não foi contaminada por influências alheias e que sofre e que geme por si [...]" (Gazeta de Notícias apud Cabral, 1997:72-3).

Em Paris, Les Batutas, anunciados como "les rois du rythme et de le samba", mostraram o repertório já conhecido do público brasileiro, com exceção de um samba especialmente composto para aquela ocasião e que agradou muito, o Les Batutas, com letra 
em francês de Duque e música de Pixinguinha: Nous sommes Batutas/ Batutas, Batutas/ Venus du Brésil/ Ici tout droit/ Nous sommes Batutas/ Nous faisons tout le monde/ Danser le samba/ Le samba se danse/ Toujours en cadence/ Petit pas par ci/ Il faut de l'éssence/ Beaucoup d'élégance/ Le corps se balance/ Dansant le samba/ La musique est simple/ Mais très rythmique/ Nous sommes certains/ Que ça vous plaira/ Nous sommes Batutas/ Batutas uniques/ Pour faire tout le monde/ Danser le samba (Cabral, 1997:77-8).

Bem-sucedidos e bastante requisitados, os Batutas permaneceriam em Paris por mais seis meses, regressando em agosto de 1922. Certamente, a fácil e calorosa acolhida dos Batutas na França explica-se, além do talento da banda, por já haver um interesse pela cultura negro-africana, suscitado por alguns jovens artistas europeus. Aliás, essa receptividade à música negra estendia-se também aos ritmos negros norte-americanos (em especial o jazz) e caribenhos, sendo que, principalmente após a Primeira Guerra Mundial, vários músicos desses lugares emigrariam para a França.

\section{Considerações finais}

Se o samba foi, ao longo das três primeiras décadas do século $\mathrm{XX}$, conquistando paulatinamente o gosto musical de uma significativa parcela da população brasileira, verifica-se uma cisão na sensibilidade estética das elites do período no que se refere à aceitação desse ritmo popular, que provoca uma oscilação entre o elogio e o repúdio ao mesmo. Para uns, só podia ser considerada "música entre aspas" o que os 8 Batutas apresentavam em seus shows. Para outros, o que faziam não era "arte negra" mas "arte brasileira" da melhor qualidade.

No entanto, se o ritmo fruído por todos era o mesmo, seus significados e usos eram diversos. Para as classes populares, o samba poderia servir para ridicularizar as autoridades e subverter a hierarquia social, fazendo do papa, um dançarino de maxixe: pois o próprio Padre Santo/ sabendo o gosto que tem/ virá de Roma ao Brasil/ dançar maxixe também (Maxixe aristocrático, José Nunes, 1904); do padre, um macumbeiro: ai meu bem/ tu não me tens amor/ vou na macumba do padre/ vou lá pedir por favor (Macumba do padre, Armando Vampa, 1925); ou do delegado de polícia, que proibira os instrumentos musicais, um sambista e a encarnação de um deles através da alcunha de "seu Tamborim": minha 
Nossa Senhora/ Sinhô do Bonfim!/ ainda hei de sambá/ com "seu" Tamborim (anônimo, 1907). Poderia ainda ser usado para louvar os heróis populares, como o samba de Sinhô intitulado Sete Coroas (1922), que homenageava o famoso malandro que dá nome à composição e que era amigo do autor.

Era também através dele que muitos sambistas podiam reafirmar a sua fé, apesar da intensa perseguição policial aos cultos afro-brasileiros: aos maus-olhados/ isto não ligamos/ pois com arruda/facilmente lhe tiramos/ e para a inveja/ temos uma figa/ feita na África/ com o bom guiné de riga (Resposta à Inveja, Sinhô, 1917). O samba permitia-lhes ainda expressar suas querelas afetivas vividas nas relações íntimas, como bem o revelam os títulos de alguns sambas: Tu qué Tomá meu Home (1929, Ary Barroso e Olegário Mariano), Esse Mulato vai ser Meu (1930, Ary Barroso e J. Carlos), O que tu Qué, não Dô (1930, revista É do outro Mundo), Essa Nega Qué me Dá (1921, Caninha e Lezute), Vamos Deixar de Intimidade (1929, Ary Barroso), Sim, mas Desencosta (1930, Cândido das Neves).

Mas era ainda esse mesmo samba que encantava alguns artistas franceses, os quais, inspirados nos princípios cubistas e enfadados com a arte parisiense, viam no maxixe O Boi no Telhado uma oportunidade de contato com uma sonoridade exótica e sedutora. Por sua vez, o poeta modernista Mário de Andrade, "redescobrindo o Brasil", deixaria registrada numa poesia sua admiração pela cadência do samba nas ruas do Rio de Janeiro, "tão sublime, tão África”.

Esse samba polissêmico seria amplificado pelos recursos audiovisuais que a nascente cultura de massas ia aos poucos implementando. Contudo, como procurei mostrar, o processo de nacionalização do samba é ambíguo e conflituoso e envolveu vários atores sociais. Com refinada habilidade política, alguns músicos populares conseguiram, de alguma forma, ocupar as brechas que a modernidade lhes abria. Como vimos, o "Rio da Regeneração" e o "Rio das malocas" não eram excludentes, o que não quer dizer que de suas relações estivessem ausentes os conflitos sociais. Na privacidade das casas das tias baianas - como a da tia Ciata -, no recato da mansão dos Guinle ou mesmo nos jardins do palácio presidencial do Catete tinha lugar uma interseção desses dois mundos, o erudito e o popular, que certamente dinamizou e formou o samba que explodiria nas décadas seguintes.

Mas isso restringe-se à esfera privada, pois no espaço público essa convivência não é revelada, uma vez que significaria reconhe- 
cer o negro como ator político e, como vimos, naquele momento histórico, diante do suposto perigo de descontrole social provocado pelas hordas de negros "bárbaros", recém-egressos da escravidão, a República vacilou em incorporar o negro como integrante do corpo político da nação.

Com efeito, este olhar ambivalente sobre o samba, relacionava-se diretamente ao lugar ambíguo que o negro ocupava no contexto intelectual da época. Dessa forma, se o legado cultural do negro fazia dele um ator social na Primeira República, o paradigma evolucionista impedia a sua incorporação ao novo pacto como ator político. A mestiçagem eugênica dos anos 10 e 20, que insere-se em um debate mais político do que científico, não nos permite estabelecer uma continuidade entre a mesma e o novo enfoque cultural que a miscibilidade ganhará nos anos 30 e 40. Esta só se consolidará com a substituição do paradigma evolucionista social - vigente até finais da década de 20 - pelo culturalismo, quando então a miscigenação deixará de ser um espectro e se tornará um fator crucial para a sinalização da singularidade nacional.

A Primeira República brasileira, ao deixar de lado a gramática política anterior, terá que forjar as regras de um novo pacto social. As autoridades republicanas se recusam a reconhecer a produção cultural presente na Festa da Penha, nas casas das tias baianas, nas sedes dos ranchos e cordóes carnavalescos, no teatro de revistas. Não será, portanto, nesse Rio de Janeiro negro que se buscará a originalidade da cultura brasileira.

No interior de toda essa produção cultural são gestados determinados ícones que evocam uma certa brasilidade mas identificada com as classes populares, tais como: a "mulata feiticeira", a "favela mulata" ou o maxixe "que tem sua arte". Porém esses ícones permaneceram no campo da experiência vivida da cultura e não foram incorporados ao campo da política, cujo acesso estava vedado às classes populares. Dessa forma, não será com esse tecido social que se construirá a República no Brasil, uma vez que o projeto pedagógico republicano, naquele momento, era o de educar, higienizar e civilizar as massas.

Carvalho (1990:141) certamente tem razão quando afirma que a República brasileira, diferentemente da francesa, era desprovida de densidade popular suficiente que tornasse possível refazer o imaginário social, o que a teria conduzido ao fracasso em seu intento de formulação de uma simbologia nacional. Contudo, para além dessa motivação política, creio que podemos ensaiar também uma explicação cultural para a compreensão desse. A razão da im- 
popularidade da República talvez resida menos na falta de habilidade política dos republicanos para empolgar as massas, ou na incapacidade destas para compreendê-los, e mais na "eficácia simbólica” (Lévi-Strauss, 1996) da realeza no país. Assim, o fato de os únicos ícones republicanos bem-sucedidos (o hino e a bandeira) estarem diretamente vinculados ao imaginário monárquico anterior, talvez deva-se à "força da tradição" (Mayer, 1990) dos símbolos imperiais, ancorados, ao que parece, numa forte comunidade de imaginação.

Lilia Schwarcz analisou a construção simbólica da imagem pública do imperador D. Pedro II, investigando a elaboração do imaginário coletivo da monarquia brasileira no século passado. A autora destaca que, para legitimar-se, essa monarquia tropical, cercada de repúblicas por todos os lados, investiria a fundo nos cerimoniais de afirmação da realeza e na promoção da figura pública do Imperador (Schwarcz, 1998:35-43). Segundo a autora, a realeza brasileira soube dialogar não só com a tradição monárquica que lhe era anterior, mas também com o seu próprio contexto e suas realidades multifacetadas, o que lhe garantiu êxito na produção de símbolos de cultura política e também alavancou a popularidade do "monarca tropical" D. Pedro II. Assim, na construção desse imaginário imperial, estabeleceu-se uma via de mão dupla: "se o imaginário popular se nutriu da realeza, e de certa maneira se 'europeizou', é possível supor o oposto: a monarquia brasileira se impregnou de elementos da cultura local" (ibidem:520).

Com relação à Primeira República, é na cultura erudita e não na cultura popular que os governantes vão buscar inspiração para a criação de uma simbologia. Diferentemente do regime anterior, aqui não há possibilidade de comunicação entre a voz oficial e os "uivos de africanos em samba". Essa ausência de diálogo implicará na falta de suporte popular para os símbolos republicanos, uma vez que não se apoiarão numa comunidade de sentido.

Dessa forma, se a Monarquia foi capaz de ouvir e ser ouvida pela população do país, a Primeira República foi incapaz de fazê-lo. Entretanto, a nova ruptura política dos anos 30 e 40 tornou premente a renegociação do pacto social anterior. Nesse momento, será criada uma nova simbologia e difundem-se rapidamente, para dentro e para fora do país, as imagens idílicas da "aquarela brasileira", povoada por mulatas sensuais e por malandros musicais que convivem em harmonia racial nessa "terra de samba e pandeiro".

O populismo procurará se legitimar apropriando-se de alguns dos elementos da cultura popular-dentre eles o samba-, que 
já estavam culturalmente disponíveis na sociedade brasileira da Primeira República e tinham grande ressonância junto à população, alçando-os com êxito à categoria de símbolos nacionais.

Para se compreender o sucesso da implantação dessa nova simbologia, vale observar que sua matéria-prima são, principalmente, as tradiçõos culturais negras. E aqui importa observar, como faz Montes (1996-97) ao comentar o ethos barroco presente na cultura brasileira, que estamos diante de fragmentos de uma história de longa duração, "inseparável das condiçôes de subordinação e resistência do negro nas Américas” (p.23). Retraduzida e ressignificada pela marca da presença negra no país, a festa barroca colonial é a matriz de uma cultura brasileira da festa a qual, por sua vez, está impregnada de uma estética negra, construída sob as formas sensíveis da música, da dança, do canto. Somos então levados a pensar em uma circularidade da cultura erudita e popular no país. Dessa forma, "os ventos da modernidade que sopram ao longo do processo de independência e de constituição dos Estados nacionais no continente latino-americano desarticularão como forma hegemônica global esta barroca cultura da festa que não separa o sagrado e o profano. Assim, à exceção do Carnaval e de algumas poucas celebrações religiosas, aos poucos ignorada ou desprezada pelas elites, ela irá permanecer como memória ou forma viva apenas entre os segmentos populares [...]" (1998: 157).

Finalmente, talvez possamos dizer que a incorporação da herança negra à esfera pública correspondeu a uma opção política feita pelo governo Vargas, agora em um novo contexto histórico no qual o velho fantasma da "ressurreição da barbaria" já não rondava mais a elegante Avenida Central.

\section{Notas}

1. Sobre o assunto, consultar Soares (1998).

2. A respeito desse assunto, ver Cunha (2001).

3. Sidney Chalhoub afirma que "[...] o contexto histórico em que se deu a adoção do conceito de 'classes perigosas' no Brasil fez com que, desde o início, os negros se tornassem os suspeitos preferenciais” (1996:20-23).

4. Ao que parece, a música sertaneja ou caipira de São Paulo, por exemplo, diferentemente do samba do Rio de Janeiro, não foi vista como unidade nacional nem nas primeiras décadas do século XX, nem pela parca produção bibliográfica dedicada ao assunto. Nesse sentido, ela ficou relegada à categoria de "música regional paulista". Este embotamento da memória da presença da música caipira paulista no cenário musical nacional - e também do samba de São Paulo e de outras regiōes do país -, 
certamente deve ser creditada, ao menos em boa parte, à grande relevância do samba carioca no imaginário social brasileiro.

5. Procurando investigar de que maneira e por quais motivos se cristalizou e difundiu a imagem do sabá diabólico na Europa da Idade Moderna, o historiador Carlo Ginzburg (1991), cuja análise está situada entre a história e a antropologia, sugere que o estereótipo do sabá constituiu-se numa “'formação cultural de compromisso', resultado híbrido de um conflito entre cultura folclórica e cultura erudita” (p. 22).

6. A "pequena África” do Rio de Janeiro, no alvorecer do século XX, abrangia os bairros da Cidade Nova, Gamboa, Saúde e adjacências. Durante o Império, a região restringia-se aos arredores do Paço e possuía um alto grau de concentração de africanos, crioulos e mestiços. Em 1849, por exemplo, de cada três habitantes, um era africano (Schwarcz, 1998).

7. Tiago Gomes (2001) publicou uma resenha sobre o livro O Mistério do Samba, onde faz algumas críticas bastante pertinentes. Ele destaca: “[a] ausência de pesquisa em fontes originais, [o] pouco interesse pelas especificidades do objeto estudado (como a massificação cultural, no caso do samba) [e a] contextualização histórica insuficiente" (p. 455).

8. No tocante à atuação dos capoeiras durante a segunda metade do século XIX, assistimos a um enlace entre os domínios da ordem e da desordem. Isso fica patente não só quando nos deparamos com a presença massiva de capoeiras nas fileiras da Guarda Nacional, do Exército e da própria polícia no transcorrer do Segundo Reinado, mas, principalmente, ao atentarmos para a arregimentação das maltas de capoeira por políticos do Império - em especial aqueles ligados ao Partido Conservador - e para sua composição étnica e social, uma vez que não apenas negros mas também imigrantes portugueses e filhos da fina flor da elite delas faziam parte (Soares, 1998 Reis, 2000).

9. Ivone Maggie (1992), ao estudar os processos criminais movidos contra os praticantes de religiōes afro-brasileiras nas primeiras décadas do século XX no Rio de Janeiro, atesta uma certa cumplicidade entre acusadores e réus, uma vez que ambos participam das mesmas "premissas culturais". Os peritos, por exemplo, em parte devido a sua própria origem social - a mesma, aliás, da maioria dos acusados -, eram certamente freqüentadores de terreiros e, portanto, conhecedores dos rituais dos cultos. Dessa forma, esses policiais atuariam como mediadores entre os juízes, promotores e advogados, de um lado, e os crentes, de outro, todos compartilhando do mesmo sistema de crenças (pp. 160; 166).

10. Ainda que seja de minha inteira responsabilidade, devo essa observação aos colegas do curso de pós-graduação "Do afro ao brasileiro: religião e cultura nacional", ministrado pelo Prof. Dr. Vagner Gonçalves da Silva na Universidade de São Paulo, $1^{\circ}$ semestre de 2003.

11. Sérgio Buarque de Holanda (1936/1979), em busca do que chama de "traços definidores do caráter brasileiro", aponta para a indistinção entre o domínio do público e do privado, cuja maior expressão encontra-se na figura do "homem cordial". Resultado histórico e social, o "homem cordial", tal como o vê o autor, representa, sobretudo, uma denúncia ao autoritarismo da sociedade brasileira, à incompletude e à fragilidade de nossas instituições políticas que impedem a plena realização e consolidação de um espaço público democrático. 


\section{Letícia Vidor de Sousa Reis}

12. Em São Paulo, particularmente nas primeiras duas décadas do século XX, a música sertaneja gozava de grande prestígio, destacando-se aí o compositor Fernando Lobo, que ficaria conhecido como Marcelo Tupinambá, o cantor Paraguaçu (Roque Ricciardi, 1894-1976) e também o excelente violonista e tocador de cavaquinho Canhoto (Américo Jacomino, 1889-1928) (Cabral, 1996b:15).

13. Fenerick (2002), atendo-se ao período que vai de 1920 a 1945, analisa de que maneira os modernos meios de comunicação de massa (entre outros fatores) atuaram no processo de construção do moderno samba brasileiro ao introduzirem modificações no modo de produção e nos significados sociais desse ritmo.

14. Para uma análise minuciosa e com alguns pontos de convergência com a que tento aqui, ver o livro Feitiço Decente (2001) de Carlos Sandroni (parte I, capítulo 5).

15. Para uma discussão sobre a impropriedade do debate acerca do "verdadeiro" berço do samba, se Rio ou Bahia, consulte-se o artigo de Ari Lima "O samba nasceu na Bahia? Diga, Sinhá / Ou no Rio de Janeiro? Responda, Sinhô”, publicado no jornal A Tarde, Suplemento Cultura, Salvador, 8.2.1997.

16. Fernando Mencarelli (1999), em seu estudo sobre a peça de teatro de revista O bilontra (1886), escrita por Arthur Azevedo e Moreira Sampaio, a qual inaugura um novo gênero teatral no Brasil, a revista de ano, analisa os diversos sentidos que a peça apresenta para seus espectadores. Dessa forma, por intermédio do universo teatral carioca das duas últimas décadas do século XIX, procura adentrar a história social e cultural do Rio de Janeiro da época.

17. É possível que Carmen Miranda também tenha nela se inspirado para compor seus turbantes de frutas tropicais.

18. Sandroni (2001), em seu estudo de cunho etnomusicológico sobre as transformações do samba no Rio de Janeiro entre 1917 e 1933, aponta para a existência de dois modelos rítmicos. O primeiro deles seria o "paradigma de tresillo", presente na música popular brasileira do século XIX até finais dos anos 1920 e o segundo seria o "paradigma do Estácio", que inauguraria um novo estilo de samba que viria a se tornar o samba carioca por excelência.

19. Foi em São Paulo, como mostra Sevcenko (1998a) em sua análise sobre a emergência do modernismo paulista, que as impressôes e os registros acerca da cultura popular de raiz negra e indígena, reelaborados por um grupo de intelectuais, determinam a chamada "redescoberta do Brasil" e conformam um projeto cultural nativista que, em busca da memória colonial do país, procura resgatar as raízes populares de sua formação cultural. É principalmente no tipo sertanejo que se almeja encontrar a originalidade brasileira. Os modernistas paulistas se inspiravam sobremaneira nas novas tendências artísticas francesas, preconizadas por Picasso, Jean Cocteau, Darius Milhaud, Fernand Léger e Blaise Cendrars, dentre outros (Sevcenko, 1998a).

20. George Yúdice, em seu artigo "A funkificação do Rio", considera que os adeptos do funke do hip-hop-majoritariamente jovens da periferia - vêm questionando de forma radical, na sua produção musical dos anos de 1980 e 1990, a idéia de harmonia racial e social que supostamente existiria no Brasil. O autor enfatiza que: “[...] por meio das músicas novas e nada tradicionais como o funke o hip-hop, os jovens procuram estabelecer novas formas de identidade desvinculadas das proclamadas premis- 
“O que o rei não viu”: música popular e nacionalidade no Rio de Janeiro...

sas do Brasil como uma nação sem diversidades conflitantes. Ao contrário, a música é sobre a desarticulação da identidade nacional e do cidadão local" (1997:27).

\section{Referências bibliográficas}

ALENCAR, Edigar de (1980). O carnaval carioca através da música. Rio de Janeiro/São Paulo, Freitas Bastos.

(1981). Nosso Sinhô do samba. Rio de Janeiro, Funarte.

BILAC, Olavo (1906). "A festa da Penha”. Kosmos, no 3, outubro, Rio de Janeiro.

CABRAL, Sérgio (1997). Pixinguinha: vida e obra. Rio de Janeiro, Editora Lumiar.

_ (1996a). As escolas de samba do Rio de Janeiro. Rio de Janeiro, Editora Lumiar. (1996b). A MPB na era do rádio. São Paulo, Moderna (Col. Polêmica).

CANDIDO, Antônio (1970). "Dialética da malandragem". Revista do Instituto de Estudos Brasileiros, no 8, São Paulo.

CARVALHO, José Murilo (1990). A formação das almas: o imaginário da República no Brasil. São Paulo, Companhia das Letras.

(1987). Os bestializados: o Rio de Janeiro e a República que não foi. São Paulo, Companhia das Letras.

CHALHOUB, Sidney (1996). Cidade febril: cortiços e epidemias na Corte Imperial. São Paulo, Companhia das Letras.

CUNHA, Maria Clementina Pereira (org.) (2002). "Vários Zés, um sobrenome: as muitas faces do senhor Pereira no carnaval carioca da virada do século". In: Carnavaise outras $f(r)$ estas: ensaios de história social da cultura. Campinas, Editora da Unicamp/Cecult.

2001. Ecos da folia: uma história social do carnaval carioca entre 1880 e 1920. São Paulo, Companhia das Letras.

EFEGÊ, Jota (1985). Meninos, eu vi. Rio de Janeiro, Funarte/Instituto Nacional de Música.

_ (1974). Maxixe, a dança excomungada. Rio de Janeiro, Conquista (Col. Temas Brasileiros).

FENERICK, José Adriano (2002). Nem do morro, nem da cidade: as transformações do samba e a indústria cultural (1920-1945). Tese de doutorado em História, FFLCH, Universidade de São Paulo.

FREITAS, Affonso A. (1985). Tradições e reminiscências paulistanas. São Paulo, EDUSP/Itatiaia.

FREYRE, Gilberto (1950). Casa-grande \& senzala. (6a ed.). Rio de Janeiro, José Olympio, 2 vols. (1 ${ }^{\text {a }}$ ed.: 1933 ).

FRY, Peter (2001). "Feijoada e soul food 25 anos depois". In: N. Esterci, P. Fry e M. Goldenberg (orgs.), Fazendo Antropologia no Brasil. Rio de Janeiro, DP\&A Edito$\mathrm{ra} / \mathrm{CAPES}$.

_ (1995-96). "O que a Cinderela negra tem a dizer sobre a 'política racial' no Brasil”. Revista USP, no 28, dez./jan./fev., Dossiê Povo Negro - 300 anos.

GARDEL, André (1996). O encontro entre Bandeira e Sinhô. Rio de Janeiro, Secretaria Municipal de Cultura do Rio de Janeiro, Departamento Geral de Documentação e Informação Cultural. 


\section{Letícia Vidor de Sousa Reis}

GINZBURG, Carlo (1991). História noturna: decifrando o sabá. São Paulo, Companhia das Letras.

GOMES, Tiago de Melo (2001). "Resenha do livro O mistério do samba, de Hermano Vianna". Revista Brasileira de História: Espaços da Política, vol. 21, no 42, pp. 435-455.

HOBSBAWM, Eric \& RANGER, Terence (1984). A invenção das tradiçôes. Rio de Janeiro, Paz e Terra.

HOLANDA, Sérgio Buarque de (1979). Raizes do Brasil (30a ed.). Rio de Janeiro, José Olympio (1 ${ }^{\mathrm{a}}$ ed.: 1936).

LÉVI-STRAUSS, Claude (1996). Antropologia Estrutural. (5a ed.). São Paulo, Tempo Brasileiro.

MAGGIE, Yvonne (1992). Medo do feitiço: relaçôes entre magia e poder no Brasil. Rio de Janeiro, Arquivo Nacional.

MAYER, Arno J. (1990). A força da tradição: a persistência do Antigo Regime. São Paulo, Companhia das Letras.

MENCARELLI, Fernando Antonio (1999). Cena aberta. A absolvição de um bilontra e o teatro de revista de Arthur Azevedo. Campinas, Editora da Unicamp/Cecult.

MONTES, Maria Lúcia (1996-97). "O erudito e o que é popular - estética negra e espetáculo de massa no desfile das escolas de samba”. Revista USP, no 32, dez.-fev., Dossiê Sociedade de Massa e Identidade.

(1998). "Entre o arcaico e o pós-moderno: heranças barrocas e a cultura da festa na construção da identidade brasileira”. Revista Sexta-Feira: Festas, no 2, abril, São Paulo, Pletora.

MORAES FILHO, Mello (1979). "Capoeiragem e capoeiras célebres". In Festas e tradições populares. São Paulo, EDUSP/Itatiaia ( $1^{a}$ ed.: 1893).

MOURA, Roberto (1983). Tia Ciata e a Pequena África no Rio de Janeiro. Rio de Janeiro, Funarte.

PEREIRA, Carlos Alberto Messeder (2003). Cacique de Ramos: uma história que deu samba. Rio de Janeiro, E-Papers.

REIS, Letícia Vidor de Sousa (1999). Na batucada da vida: samba e política no Rio de Janeiro (1889-1930). Tese de Doutorado em Antropologia, Universidade de São Paulo.

(2000). O mundo de pernas para o ar: a capoeira no Brasil. (2a ed.). São Paulo, Publisher Brasil.

\& SCHWARCZ, Lilia Moritz (orgs) (1996). Negras imagens: ensaios sobre cultura e escravidão no Brasil. São Paulo, Edusp/Estação Ciência.

RODRIGUES, Nina (1977). Os africanos no Brasil. São Paulo, Cia. Editora Nacional (1ª ed.: 1933).

RUIZ, Roberto (1984). Araci Cortes: linda flor. Rio de Janeiro, Funarte/INM/Divisão de Música Popular.

SALVADORI, Maria Angela Borges (1990). Capoeiras e malandros: pedaços de uma sonora tradição popular (1890-1950). Dissertação de Mestrado em História, Unicamp.

SANDRONI, Carlos (2001). Feitiço decente. Rio de Janeiro, Ed. UFRJ/Jorge Zahar Editor. 
SCHWARCZ, Lilia Moritz (1998). As barbas do imperador. D. Pedro II, um monarca nos trópicos. São Paulo, Companhia das Letras.

_ (1993). O espetáculo das raças. São Paulo, Companhia das Letras.

SEVCENKO, Nicolau (1998a). Orfeu extático na metrópole: São Paulo, sociedade e cultura nos frementes anos 20. São Paulo, Companhia das Letras.

_ (org.) (1998b). "A capital irradiante: técnica, ritmos e ritos do Rio". In História da vida privada no Brasil. República: da Belle Époque à era do rádio. São Paulo, Companhia das Letras, vol. 3.

SEVERIANO, Jairo \& MELLO, Zuza Homem de (1998). A canção no tempo: 85 anos de músicas brasileiras. (2a ed.). São Paulo, Editora 34, vol. 1: 1901-1957.

SOARES, Carlos Eugênio Líbano (1998). A negregada instituição: os capoeiras na corte imperial. 1850-1890. ( $2^{a}$ ed.). Rio de Janeiro, Ed. Access.

SOIHET, Rachel (1998). A subversão pelo riso. Rio de Janeiro, Ed. da Fundação Getulio Vargas.

TINHORÃO, José R. (1972). Música popular de indios, negros e mestiços. Petrópolis, Vozes.

(1998). História social da música popular brasileira. São Paulo, Editora 34.

VASCONCELOS, Ary (1985). A nova música da República Velha. Rio de Janeiro, Editora do Autor.

VELLOSO, Monica Pimenta (1996). Modernismo no Rio de Janeiro. Rio de Janeiro, Ed. da Fundação Getulio Vargas.

VIANNA, Hermano (1995). O mistério do samba. (2a ed.). Rio de Janeiro, Zahar/Editora da UFRJ.

YÚDICE, George (1997). "A funkificação do Rio". In M. Herschmann (org.), Abalando os anos 90. Funk e hip-hop - Globalização, violência e estilo cultural. Rio de Janeiro, Rocco. 